PALEO

Revue d'archéologie préhistorique

$27 \mid 2016$

Varia

\title{
The Châtelperronian of Germolles (Grotte de la Verpillière I, Mellecey, Saône-et-Loire, France)
}

Harald Floss, Christian Hoyer and Heike Würschem

\section{(2) OpenEdition}

1 Journals

Electronic version

URL: http://journals.openedition.org/paleo/3242

DOI: 10.4000/paleo.3242

ISSN: $2101-0420$

Publisher

SAMRA

Printed version

Date of publication: 30 December 2016

Number of pages: 149-176

ISSN: $1145-3370$

\section{Electronic reference}

Harald Floss, Christian Hoyer and Heike Würschem, « The Châtelperronian of Germolles (Grotte de la Verpillière I, Mellecey, Saône-et-Loire, France) », PALEO [Online], 27 | 2016, Online since 01 June 2018, connection on 07 July 2020. URL : http://journals.openedition.org/paleo/3242 ; DOI : https://doi.org/ 10.4000/paleo.3242

This text was automatically generated on 7 July 2020 .

\section{cc) (i) $\odot$}

PALEO est mis à disposition selon les termes de la licence Creative Commons Attribution - Pas d'Utilisation Commerciale - Pas de Modification 4.0 International. 


\title{
The Châtelperronian of Germolles (Grotte de la Verpillière I, Mellecey, Saône-et-Loire, France)
}

\author{
Harald Floss, Christian Hoyer and Heike Würschem
}

We thank the regional direction of cultural affairs, the regional service of archaeology of Burgundy, UMR 6298 ARTeHIS of the University of Burgundy, the Deutsche Forschungsgemeinschaft, the Saône-et-Loire department, the University of Tübingen, the town hall of Mellecey, the Verpillière excavation teams, the members of the PCR "Paléolithique en Bourgogne Méridional" and in particular Pierre Andriot, Laetitia Bassereau-Vauthier, Sabine Boos, Didier Cailhol, Michel Cessot, Jean Combier, René Desbrosse, Victor Donguy, Denis Dubois, Annie Dumont, Ewa Dutkiewicz, Jean-Claude Gress, André-Charles Gros, Nadine Huber, Olivier Lemercier, Stephanie Lismann, Bernard Macioszczyk, Gwenaëlle Marchet-Legendre, Catherine Michel, René Parise, Yves Pautrat, Matthieu Pinette, Michel Prestreau, Benjamin Schürch, François Sikner, Pierre Voarick and Isabelle Vernus.

\section{Introduction}

1 Since 2006, a team from Tübingen University, directed by Harald Floss, has been working in the Germolles caves, also known as the "La Verpillière caves", located on the townland of Mellecey, several kilometres west of Chalon-sur-Saône (fig. 1). The caves are north facing, and are located on the side of the Orbize Valley, a small affluent of the Saône. The Côte Chalonnaise was occupied from the Middle Palaeolithic onwards and contains several cave and open-air sites, including Saint-Martin-sous-Montaigu, Saint-Denis-de-Vaux and the Rully caves (Gros and Gros 2005). For this reason, in 2014, we set up a PCR with Yves Pautrat of the S.R.A. Bourgogne (Dijon), focusing on the Palaeolithic in southern Burgundy, which now comprises about fifty researchers (Floss et al. 2015, 2016). Research and fieldwork in Germolles Cave began during the 1860 s and the excavation history is complex. Here, we consider that it is essential to dissect the essential data too often immersed in a maze of more or less precise information. For 
the Chatelperronian, which is one of the most emblematic occupations of this cave, this observation consists in several written testimonies, such as: Nelly Connet (2002 - p. 9): "Germolles Cave (Saône-et-Loire) appears to have contained Châtelperron points and perhaps a Châtelperronian level, unfortunately undifferentiated from the other occupation levels of the cavity". Or François Bachellerie (2011 - p. 321) about Germolles: "early excavations, no clear stratigraphic information, little material," (...).

Figure 1 - Location of Grotte de la Verpillière I (Germolles) and other Châtelperronian sites in southern Burgundy.

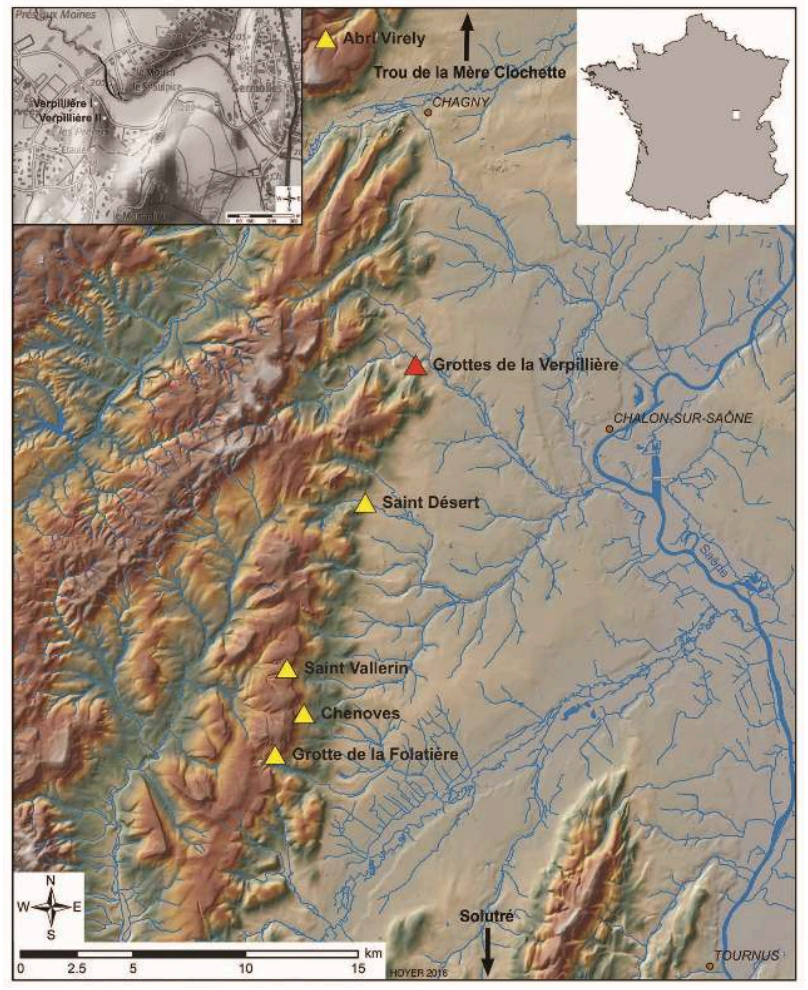

Base map: IGN France

Mapping: Ch. Hoyer

2 The aim of our contribution is thus to bring together, as objectively as possible, the existing data for the Germolles Châtelperronian from early excavations, as well as from our own work. This project contains limits, but also significant potential. In the current state of knowledge, Germolles is the easternmost Châtelperronian site, $115 \mathrm{~km}$ from Arcy-sur-Cure, $225 \mathrm{~km}$ from Ormesson and $300 \mathrm{~km}$ from Cottés. Germolles was probably occupied by the last Neanderthals and is beside contemporaneous regions already occupied by Homo sapiens (Aurignacian of the Swabian Jura) (Floss 2003). This extraordinary paleogeographic location thus warrants a study, in spite of the shortfalls of archaeological conservation.

\section{The chronology of the Palaeolithic occupation of Grotte de La Verpillière I at Germolles}

Before we examine the Châtelperronian question, it is fitting after 150 years of excavations and explorations to draw up a succinct table of the occupation phases of 
this cave, by linking the results from the early excavations $(1868-1959$, fig. 2$)$ to those from our own investigations from 2006 onwards. For the recent excavations carried out by us, we use a stratigraphic denomination system following the geological units used (GH's), which are sometimes identical to the archaeological levels, and sometimes contain several archaeological levels. The numbering does not follow the chronological attribution of the levels but the successive order of their discoveries, as well as postexcavation standardization.

Figure 2 - Site plan of the Grotte de la Verpillière I. The squares recently excavated by the team of the University of Tübingen and the areas of ancient excavations are charted. Distribution of the Châtelperronian artefacts: red: Châtelperronian points, blue: blanks (blades), yellow: cores, green: knives. The diameter of the symbols reflects the number of pieces, ranging from 1 to 8 .

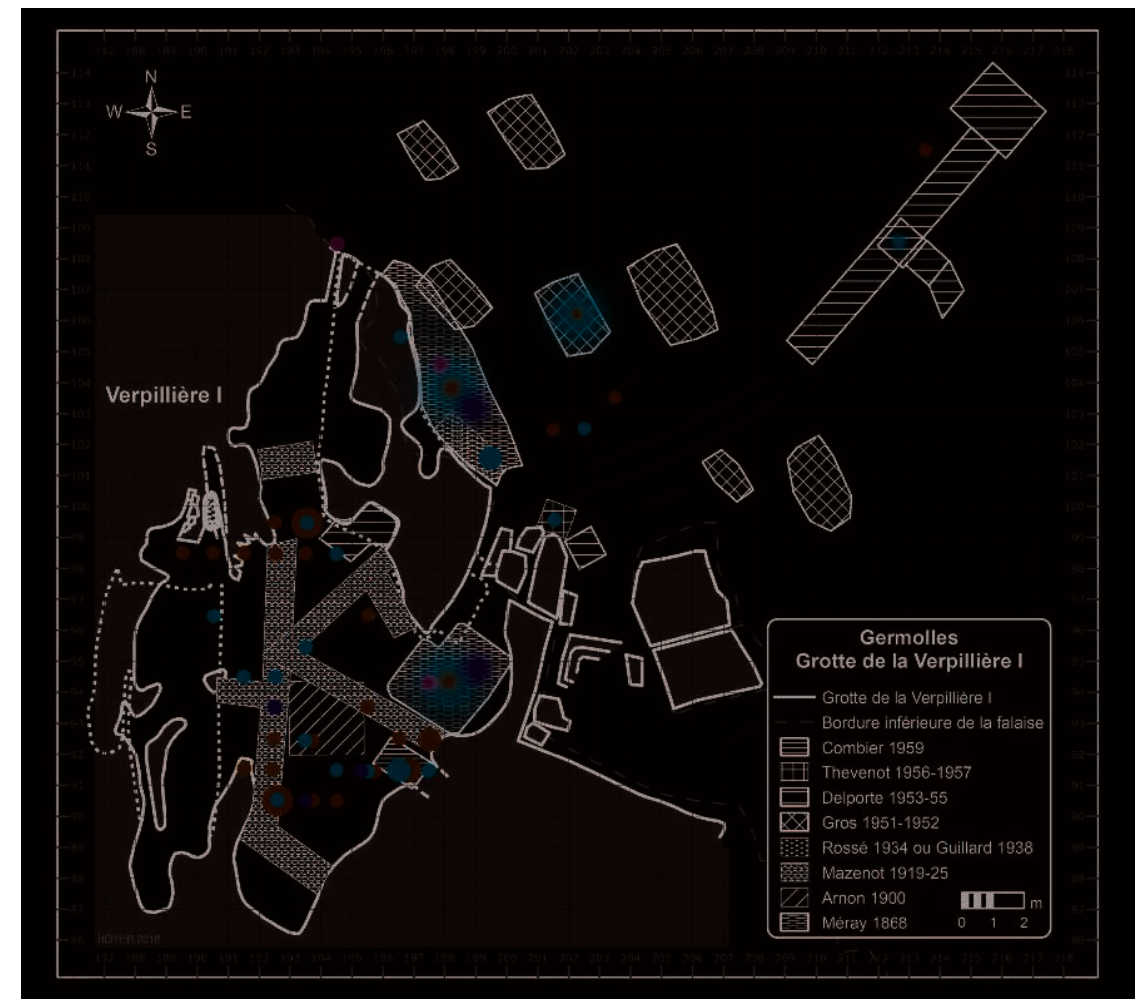

Realization: Ch. Hoyer

4 The occupation of La Verpillière I Cave begins during the Middle Palaeolithic and is marked by level GH 16, which is in position over several square metres to the west of the interior of the cave. It is conducive to palethnological observations on the internal structuration of the Neanderthal occupation (Floss et al. 2010; Litzenberg 2015; Hoyer et al. 2016). From an archaeological perspective, this level contains a classical Mousterian with the presence of Levallois debitage, and also several bifacial elements. We have an ESR /U-Th date of $51000 \pm 3000$ à $48000 \pm 3000$ for a herbivore's tooth, from the transition between GH16 and GH15 (Richard et al. 2016a; Richard et al. 2016b). We can thus deduce that level GH16 presents an older date than $50000 \mathrm{BP}$, during a cold phase from the beginning of OIS 3. In spite of the presence of bifacial elements, this level is archaeologically different to the most emblematic Middle Palaeolithic facies of the site, which is the Micoquian, in the broad sense, also called the Keilmesser groups, characterized by the presence of backed bifaces, one or several oblique tranchet blows (Pradniks) and popularized on the basis of early series, by René Desbrosse ( ) 
(Desbrosse and Texier 1973). Unlike the new cave of La Verpillière II, where there is a stratified level from this complex, our recent excavations at La Verpillière I never revealed this type of industry in an intact level. It is only in 2015 that we discovered, on the terrace of this cave, several markers of the stratigraphic position of this type of Middle Palaeolithic (GH44 to GH45). As for the dates of these Keilmesser groups at Germolles, we refer to the neighbouring Verpillière II Cave where this type of industry (Frick \& Floss 2017) was recently dated by thermoluminescence to a minimum age of 47 500 BP for the lower level GH4, 45000 BP for the upper level GH3 (Zöller \& Schmidt 2016), and a ${ }^{14} \mathrm{C}$ date of $>48200$ BP (Heckel et al. 2016).

5 The presence of small symmetric bifaces was observed in the lithic series from early excavations. They are triangular or cordate in shape, and from a techno-typological point of view, they are part of the Acheulean tradition Mousterian (see Soressi 2002). For this type of Middle Palaeolithic, the situation is the same as for the Keilmesser groups: at La Verpillière I, we have never found this industry in an in situ level. It is important to recall the presence of several large bifaces in the early series, which point to the existence of a genuine Acheulean (Gros and Gros 2005). But in the current state of research, we have no marker of the presence of this emblematic Lower Palaeolithic complex. Moreover, in the north of Burdundy, regularly-shaped bifaces were found in OIS 5 (Deloze et al. 1994).

6 In chronological order, the Chattelperronian, the main motive of this contribution, comes next. Fortunately, the 2014 excavation brought to light this complex in an intact level (GH40), totally coloured in red by the presence of iron oxides (hematite) (fig. 3). We obtained a ${ }^{14} \mathrm{C}$ date on bone of $49600 \pm 3900 \mathrm{cal}$. BP (OxA 32 235) for this level. This date appears to be slightly too old, particularly in light of the current Châtelperronian dates for Arcy-sur-Cure (Grotte du Renne), which vary between 40500 and 45000 cal. BP (Soressi and Roussel 2014; Hublin et al. 2012).

7 As for the stratigraphy in this sector (fig. 3), this is the only zone in La Verpillière I where we found the Chatelperronian in position. The section begins at the base of the source rock (GH6), reveals sterile levels (GH 2, 4, 22), the Mousterian of GH 15b (which corresponds to GH16 in the west of the cave), GHs 41 (Mousterian), the Chatelperronian (GH 40) until the Aurignacian (GH 15c, which fell towards the bottom after early excavations). 
Figure 3 - Grotte de la Verpillière I, the Châtelperronian layer GH 40 in its stratigraphic context. On top: profile image based on photogrammetry. Bottom left: Photograph of layer $\mathrm{GH} 40$. Bottom right: Photograph of Layer GH 40, modified by DStretch software.

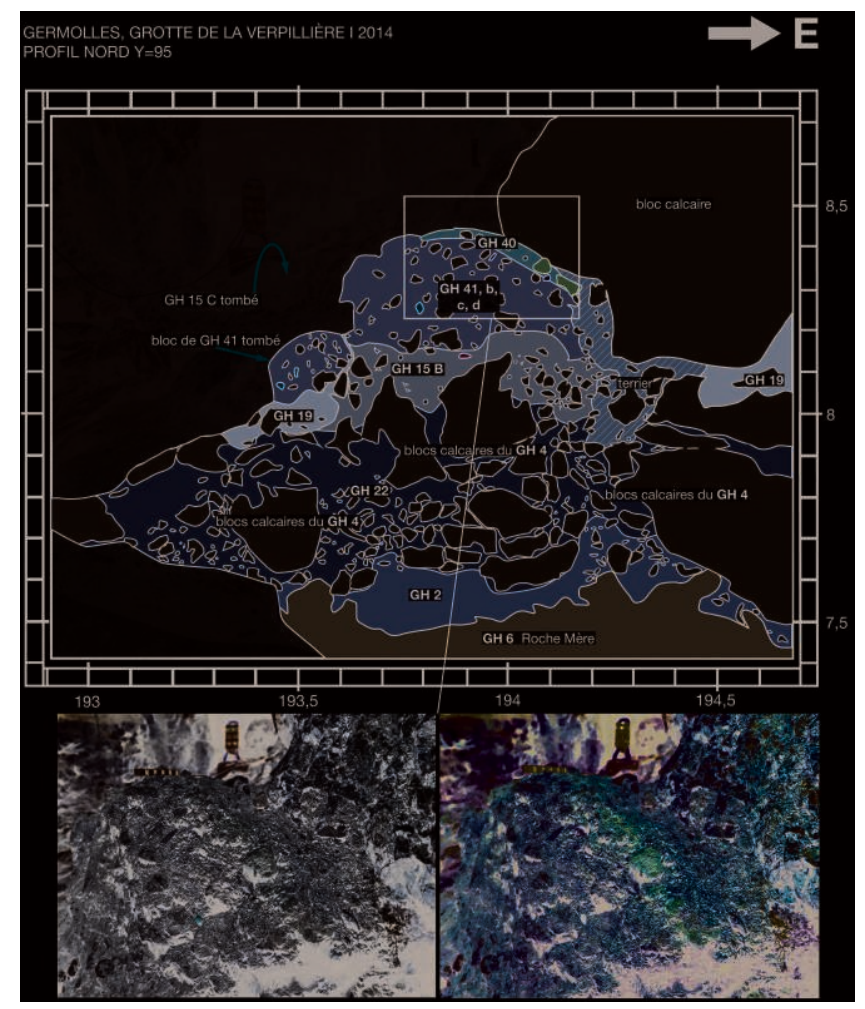

Photos and realization: Ch. Hoyer

8 As for the Aurignacian, we recently detected the presence of the Protoaurignacian at Germolles, based on certain types of cores with intersecting debitage and Dufour bladelets from early excavations (Wegeng 2015; Wegeng \& Floss 2016). Without any stratigraphic marker, this statement, based on purely technological observations, does not take account of the current discussion on the genesis (or should we say the existence?) of the Protoaurignacian, either as an initial phase of the Aurignacian, or as a technological phenomenon in the Aurignacian corpus, with no chronological value.

The early Aurignacian was identified in the early excavations and yielded abundant and spectacular lithic and osseous industries. Note for example the high number of thick and classical carinated objects (see Floss 2005; Floss et al. 2013 b, 2015 a), indicating intensive lamellar on site debitage, as well as abundant artefacts in bone, wood and ivory pointing to on-site production (Tartar \& Heckel 2016; Floss et al. 2015 a). We never found this same type of Aurignacian (thick carinated objects, spears with split bases, etc.) in intact levels during our excavations. This does not mean that we did not find Aurignacian facies, but the facies we found did not display as classical characteristics as that of the early series. We found the Aurignacian, or at least an early Upper Palaeolithic with Aurignacian affinities, in several levels and in several places in the cavity (fig. 3): the most representative Aurignacian levels are GH24 and GH35. Over a surface of $1.5 \mathrm{~m}^{2}$ to the west of the cave, the Aurignacian lithic industry from GH35 is characterized by several bladelet cores and blanks from this type of debitage (Floss et al. 2013 a, fig. 27). As for the dating of the Aurignacian, we have one date of $>44300 \mathrm{BP}$ on bone (OxA 32 228) for GH24, which is a little too old, but nonetheless not shocking. 
During the course of the past years, we also dated clearly Aurignacian osseous industry elements (spears, lissoirs, awls). These dates (GrA-49 115 to 49 127) are around 32000 $\mathrm{BP}$, which makes them very recent. However, the analysis of the lamellar industry from the reworked levels of La Verpillière I (Kremmer 2015) brought to light the presence of certain types of retouched or non-retouched bladelets, pointing to the presence of a developed Aurignacian (Chiotti 2003; Pesesse and Michel 2006).

The Gravettian was only confidently recognized, for the first time, during our recent excavations. First of all, several lithic fossiles-directeurs were identified, including micro-gravettes and also, for the first time in this region of south Burgundy, several Noailles burins. During our 2009 excavations (Floss et al. 2009), outside the present cave, several metres north of the entrance, we discovered a zone with abundant Gravettian remains, also containing ornamental elements (perforated teeth). This complex was dated by several ${ }^{14} \mathrm{C}$ measurements (GrA-44 701 to 44 704, 45 482, 45 450) between 26 $010 \pm 120$ and $28900 \pm 440 \mathrm{BP}$. We also identified a Gravettian deposit inside the cave. This is GH23, at the top of a talus fan to the west of the cave, containing several backed elements.

11 The chronological sequence of the cave of La Verpillière I ends, after 30000 years of human occupation, with the possible presence of the Solutrean, in the form of one or two laurel leaf fragments, isolated remains found with a "Germolles" label, in the collection of the Geology laboratory of the University of Lyon I (Dutkiewicz \& Floss 2015). We observe the absence of the Magdalenian and the occupation ends with several isolated post-glacial remains.

\section{The Châtelperronian at Germolles}

The cave of La Verpillière at Germolles has undergone a long and complicated history of research since its discovery in 1868 (Dutkiewicz \& Floss 2015). The last coordinated excavations, before our own work, took place in the 1950s, directed respectively by André-Charles Gros, Jean Combier, Jean-Paul Thévenot and Henri Delporte. The latter was particularly interested in the Châtelperronian, after his work on the eponymous site in the Allier (Delporte 1955). After half a century of abandon and non-coordinated excavations, the Tübingen team started work on this site in 2003 by establishing a detailed plan of the cave, and began programmed excavations in 2006. Our work led to the discovery of a new cave in 2006, under the continuation of the same ledge. Since then, the $19^{\text {th }}$ century cave is called Verpillière I and the new cave Verpillière II.

13 For the Châtelperronian, only cave I has yielded data; apart from several rather insignificant elements from cave II. And it is noteworthy that the discoverer of the site, Charles Méray, described and illustrated objects subsequently identified as Châtelperron points as fossile-directeurs of this complex in 1869, calling them "knives" (Méray 1869) or "knife with a carefully worked back" (Méray and Chabas 1876, fig. 13). Charles Méray also described another object (1876, fig. 14), which belongs to the corpus of interest here, as a "borer (...), ending in a curved and retouched point" (fig. 6.1).

14 At the beginning of the $20^{\text {th }}$ century, the site of Germolles is mentioned in the famous Aurignacian battle. Henri Breuil (1909 - p. 14) includes the site in his line of argument on the Aurignacian at the beginning of the Upper Palaeolithic, without carrying out his own excavations there. Based on the discoveries of Ch. Méray, this same author (Breuil 1911 - p. 39) describes "several blades with unilateral retouch, either on the pointed 
end, or on the whole backed side" and considers them "without any possible doubt, as Châtelperron type". Nonetheless, he regrets the absence of context of these pieces, which are relatively rare, and concludes that they are from an insignificant "early Perigordian" level. In spite of the reputation and the discovery of several Chatelperronian objects from excavations during the first half of the $20^{\text {th }}$ century (Dutkiewicz 2011; Dutkiewicz \& Floss 2015), research at Germolles and interest in the Châtelperronian only increased again from the 1950s onwards. Along with the work of Armand-Calliat (1950), Abbot Guillard (1954) (Dutkiewicz 2011, fig. 40), and the young André-Charles Gros (1958), a competitive situation between Jean Combier and Henri Delporte around this site moved things forward. Today, it is the correspondence between these two authors, rather than their publications (Delporte 1953, 1955; Combier 1955, 1959), which reveals their discussions. The differences between the archaeological visions of these two researchers were considerable. Based on early excavations and on their own work (test pit by Jean Combier in 1959 inside the cave, excavations and namely a large trench in front of the cave by Henri Delporte between 1953 and 1955), the main points of discussion concern the question of the importance of the Aurignacian (less important for Delporte and appropriately important for Combier) and of the existence of an independent Châtelperronian. This latter idea was backed by Henri Delporte and called the "pure Castelperronian" (Delporte 1953 - p. 238) or "Lower Perigordian" (Delporte 1955 - p. 160), but contested by Jean Combier (1952, unpublished) who considered, at the beginning of the discussion, the few Chattelperron points as an element of the late Mousterian or a component of the Aurignacian. Later, both researchers reached agreement in a joint announcement (unpublished, no year), according to which, in spite of the lack of stratigraphic results, the Chatelperronian came before the Aurignacian, which is divided into several levels (see also Combier 1955 - p. 603). Jean Combier (1959 - p. 121) counted about twenty Châtelperron points at that time, from several collections, but he continued to adopt a critical attitude concerning the presence of the Chatelperronian (Combier 1989 - p. 274, 1990 - fig. 1). According to him, although he was totally unaware of serious reworking in the studied series, Germolles was not part of the Châtelperronian distribution area, but like the Trou de la Mère Clochette, held some kind of non-defined link with the latter: "At Germolles, near Chalon-sur-Saône, a collapsed cave or porch, listed as an "old Aurignacian" in $H$. Breuil's observations in 1911, (became the Châtelperronian), we only observe several rare backed knives among a very abundant Aurignacian, well characterized by bone points... » (Combier 1990 - p. 270, see also 277).

The extensive excavations carried out by Henri Delporte (large trench outside the cave and several test pits inside and outside the cave) (1955 - p. 160) yielded disappointing stratigraphic results, as only several dispersed Châtelperronian elements were discovered in the scree of level 1. Jean Combier undertook a small test pit in the cave and established a stratigraphy which we subsequently developed (fig. 4) (Floss et al. $2013 \mathrm{~b}$ ). Level 4 of this stratigraphic sequence, with a thickness of $10 \mathrm{~cm}$, was called the "Mousterian with flakes or the Chatelperronian", and represented the first evidence of an in situ Châtelperronian at this site (see also Floss et al. 2013 b). Today, after studying the series (Dutkiewicz \& Floss 2015), our assessment of these results is more sceptical as none of the 19 objects in question from level 4 are clearly Châtelperronian. 
Figure 4 - Grotte de la Verpillière I, stratigraphy of the test pit excavated by Jean Combier in 1959, top: sketch by J. Combier, below: summarized stratigraphy.

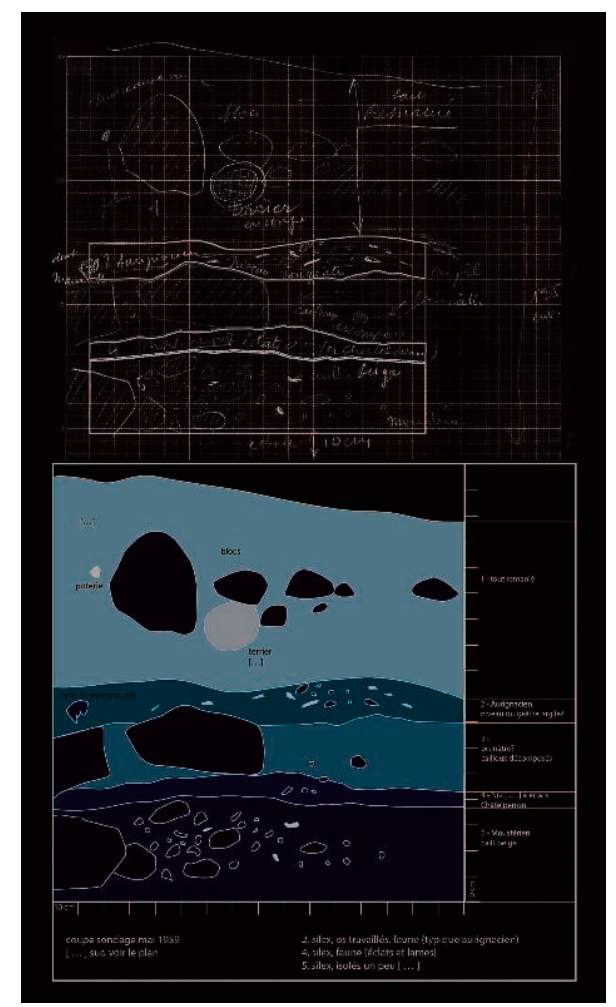

Réalisation : E. Dutkiewicz

Work on Germolles resumed again during the 1970s with the studies of René Desbrosse (Desbrosse \& Texier 1973; Desbrosse et al. 1976; Desbrosse 1982), which confirmed the presence of the Chatelperronian in situ and put it into context among a series of Perigordian sites in the east of France. In a key article, Desbrosse (1982) argued for a separate, fully Châtelperronian occupation in this site. He also mentioned, beside a series of eight well drawn Châtelperron points for the first time (Desbrosse 1982, fig. 3), the presence of a Cottés point (Desbrosse 1982, fig. 3.3) and an Abri Audi type knife (Desbrosse 1982, fig. 3.3 and fig. 3.8).

After this latter work, interest for the site of Germolles and the Châtelperronian occupation waned, probably because the cave was considered to be depleted. Over the past decades, the site was mentioned and/or mapped in several supra regional works focusing on the Châtelperronian (Harrold 1986; Bosinski 1987, fig. 4; Baffier 1999; Roussel 2011, fig. 1.1; Roussel and Soressi 2014 - p. 34; Soressi and Roussel 2014, fig. 3), Arcy-sur-Cure (Connet 2002 - p. 9), Côte Chalonnaise (Gros and Gros 2005, fig. 20), the Henri Delporte excavations (Gros 2007) or the Chatelperronian lithic technology (Pelegrin 1995 - p. 44), indicating the existence of the Châtelperronian at Germolles, but without being able to say much more.

18 The revival of work by the University of Tübingen in 2003 yielded new data and entailed a comparison of data from the early and renewed excavations. Several works attempted to monitor the paleogeography of the east of France in the thematic zone occupied by the last Neanderthals and the first modern humans in Europe (Floss 2003, 2005). A master's dissertation (Dutkiewicz 2011; Dutkiewicz \& Floss 2015) focused on a detailed reconstruction of the history of research in this cave. In addition, the new 
excavations yielded Châtelperronian elements, mostly from a reworked context (GH 1), but also in the surface levels GH 1 and 2 from the new cave, La Verpillière II (Götz 2013; Floss et al. 2013 b, fig. 3). In 2015, a first university work tackled the question of the Châtelperronian at Germolles (Würschem 2015).

\section{The stratified Châtelperronian}

19 As part of our "criminological" work reconstructing the facts, Jean Combier entrusted us with a batch of unpublished documents on Germolles. These included a manuscript stratigraphic section from the 1959 test pit in the cavity (fig. 4). We made use of this precious document in our subsequent work (Floss et al. $2013 \mathrm{~b}$, fig. 4, see also Floss et al. 2015 b - p.47; Dutkiewicz \& Floss 2015 - p. 27). On this stratigraphic section, we observe the denomination "Mousterian Level with flakes or Châtelperronian", which gave us hope of finding the first indication of an in situ Châtelperronian in this cave (Floss et al. $2013 \mathrm{~b}$ ). It is clear that the stratigraphic situation of this level points to a position around the transition between the Middle and the Upper Palaeolithic, only represented in this region by the Chatelperronian, but an analysis of the lithic series from this section, comprising a total of 81 objects, does not convincingly reveal any Châtelperronian elements. In addition, the integrity of level 4 was called into question (oral communication J. Combier (see Dutkiewicz 2011 - p. 92; Dutkiewicz \& Floss 2015 p. 29). Let us recall that the 1959 Combier section probably brought to light a level chronologically positioned towards the Middle to Upper Palaeolithic transition, but that any further chrono-cultural attribution of the series now seems to be presumptuous.

In this way, from the beginning of our work at La Verpillière I, we believed that it was possible to discover an in situ Châtelperronian (Floss et al. 2013 b - p. 336). In 2009, we brought to light a stratigraphic remnant, against the cave wall near the 1959 Jean Combier test pit, with eight distinct stratigraphic units (Floss et al. 2009, fig. 37-38, see also Bader 2011). In an identical stratigraphic position to that mentioned in the J. Combier test pit, we discovered an atypical fragment of a blade or a backed point in level 12, leading us to call this series a "transition facies" (Floss et al. 2009: p. 16). Later, during work in the northwest of the cavity, under a talus fan, which guaranteed the conservation of intact deposits, in the upper part of GH15, we identified a facies with Middle and Upper Palaeolithic characteristics, which also pointed to a transition level. Today, we are convinced that this level presents a mixed industry due to the presence of marked water erosion in this part of the cave.

21 It was only in 2014 (see Floss et al. 2014, fig. 15; Dutkiewicz \& Floss 2015 - p. 15; Floss et al. $2015 \mathrm{~b}$ ), as part of our excavations in the east-central zone of the cavity (sector E), that we came across a level attributable to the Châtelperronian in excavation squares 194/096 and 195/096 (fig. 3). It was called GH 40, following the internal denomination. It is a homogenous sandy to silty sediment with a low clay content, observed on the surface over a third of a square metre. This level is differentiated by a clear red colour due to metallic oxides, which are not derived from the decomposition process of the neighbouring limestones, but from a high hematite powder content (fig. 3). In this context, it is important to highlight the presence of a piece of hematite. Besides a reddish colour from the iron oxides, this unit shows a $30^{\circ}$ slope of in a north-easterly direction, i.e. in the axis of a large limestone block (fig. 3). The thickness of GH 40 is 8 
$\mathrm{cm}$. Towards the east, it continues under a limestone block before disappearing. The lithic series from GH 40 consists of a total of 48 artefacts, most of which $(n=40)$ measure less than a centimetre. The most significant object is a Châtelperron point in flint from the clays with flint from the Côte Chalonnaise (fig. 5.1). In addition, there is a large sub-crested blade (fig. 5.2), attributable to the same chronological context, in local flint, with a laminar removal of the dorsal surface, and the remains of preparation and cortex. The characteristics suggest soft percussion, on account of the presence of a discrete bulb and a lip. There is also a small blade fragment with traces of fire. Beside these lithic remains, GH 40 also contains datable material, such as charcoal, burnt bones and large herbivore teeth (see below).

Figure 5 - Grotte de la Verpillière I, Tübingen excavations, Châtelperronian layer (GH 40, intact): 1: Châtelperronian point, 2: secondary crested blade.
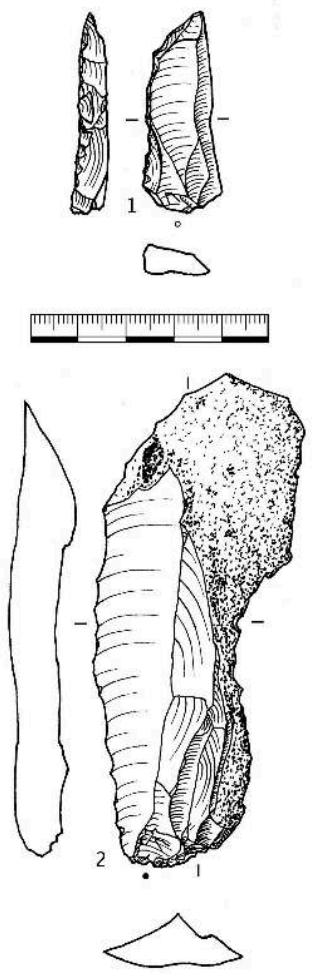

Realization: H. Würschem, Ch. Hoyer

From a stratigraphic point of view, GH 40 is surrounded by the lower level GH 41, subdivided into several sub-levels. GH 41 can be distinguished by the absence of red colouring, but is apparently characterized by the same matrix. From an archaeological point of view, GH 41 yielded a total of 434 lithic artefacts. From a techno-typological point of view, the series is attributable to the Middle Palaeolithic with the presence of the Levallois concept. We note the presence of Levallois flakes, notches and a side scraper. Sub-level GH 41d contains a bifacial element. There is also a tooth, charcoal and burnt bones, fragmented and digested by carnivores.

Lower down, a relatively thin level (GH 15b) is characterized by a Middle Palaeolithic industry extending laterally in a westerly direction, towards levels GH 16/15. Initially, there was an Aurignacian level above GH 40, between two of Charles Méray's trenches 
(fig. 2 and fig. 3). This level (GH 15c) was subsequently destabilized and slid towards the base of the early trench (fig. 3), (Bachellerie et al. 2011).

In 2015, we made a large trench with a mechanical digger (test pit 2), $25 \mathrm{~m} \mathrm{long,}$ subdivided into 10 zones. This test pit extends from the entrance of La Verpillière I to the road below the talus. From a stratigraphic point of view, the trench continued to the source rock. This base of the stratigraphy represents the paleosurface during the Palaeolithic occupation. In the upper part, the trench reveals a terrace with a width of seven metres. It is almost horizontal and thus provides ideal conditions for human occupation. Below this terrace, the rock appears to systematically crumble into steps, forming steps going down to the bottom of the valley.

In the central part of the terrace, at about five metres from the entrance of cave I, above the limestone in position, are non-disturbed deposits characterized by a very dense accumulation of bone shards, burnt bones and flint, in a sedimentary trap, in a yellow-coloured sandy clay. In light of the abundance of the archaeological objects, the corpus from this $10-\mathrm{cm}$-thick level must have been excavated manually. Below the humic surface level (GH 1), the excavation identified three geological levels, GH 44, 44b and 45, with several accumulations of artefacts. The lithic industry is particularly abundant and comprises several thousand objects, ranging from the end of the Middle Palaeolithic to the Aurignacian. Note also several Châtelperronian elements in this context, namely Châtelperron points (fig. 6.7; fig. 8.11, fig. 9.3).

Figure 6 - Grotte de la Verpillière I, Châtelperronian points. 1, 3-5: Méray excavations, 2: test pits by Gros, 6-8: Tübingen excavations.

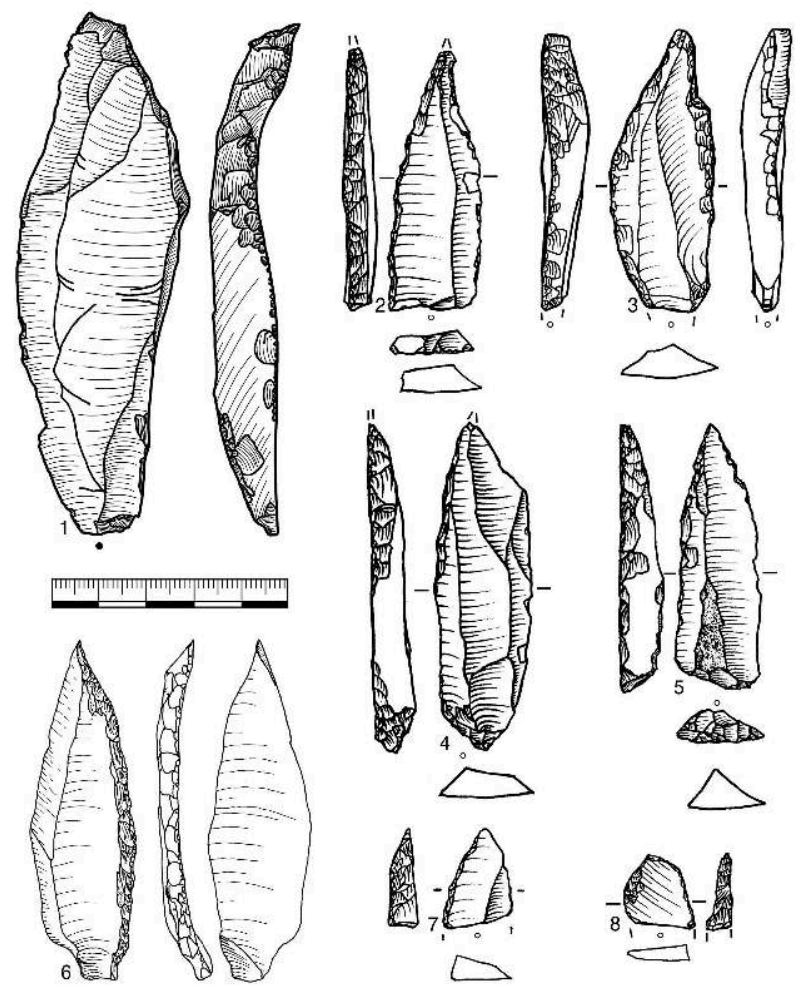

Realization: H. Würschem, Ch. Hoyer 
Figure 7 - Grotte de la Verpillière I, Châtelperronian points. 1, 2, 4-6, 8: Méray excavations, 3, 7: test pits by Gros, 9-11: Tübingen excavations.

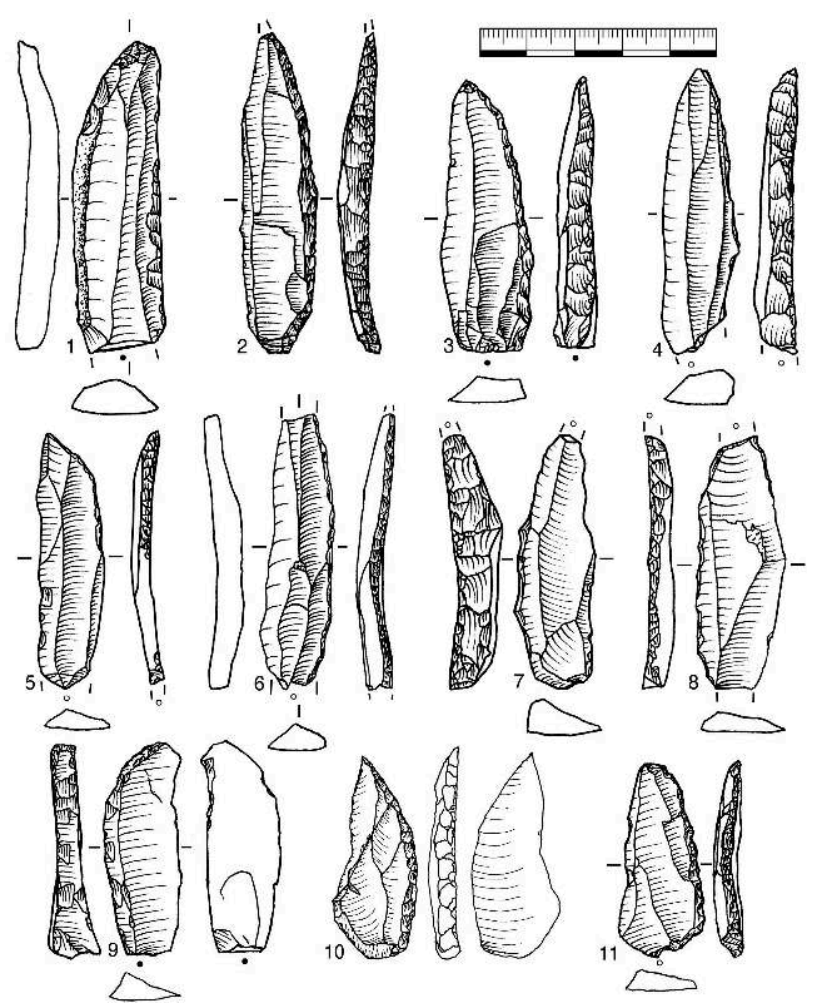

Realization: H. Würschem, Ch. Hoyer 
Figure 8 - Grotte de la Verpillière I, Châtelperronian points. 1, 2, 4-6, 11 : Méray excavations, 9: test pits by Gros, 8: unknown excavator, 3, 7, 10: Tübingen excavations.

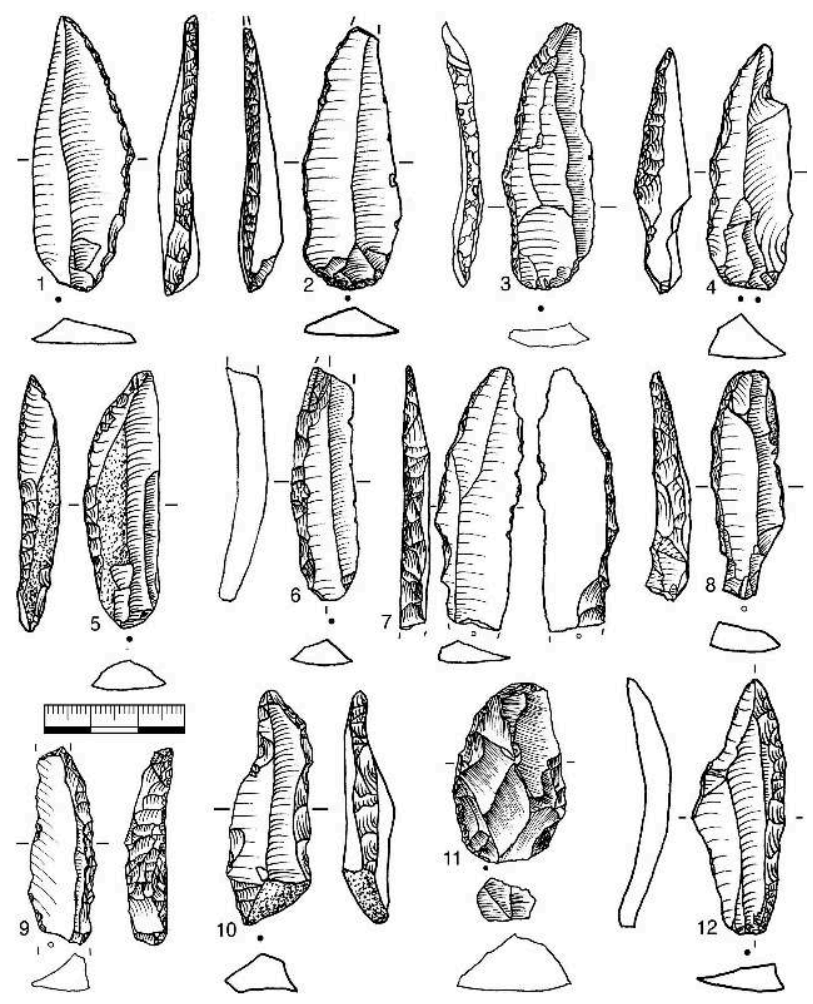

Realization: H. Würschem, Ch. Hoyer 
Figure 9 - Grotte de la Verpillière I, Châtelperronian points. 1, 3, 6, 7, 9, 12, 13: Tübingen excavations, 2 : Méray excavations, $5,8,11$ : test pits by Gros, 4: Delporte excavations, 10 : Thevenot test pit.
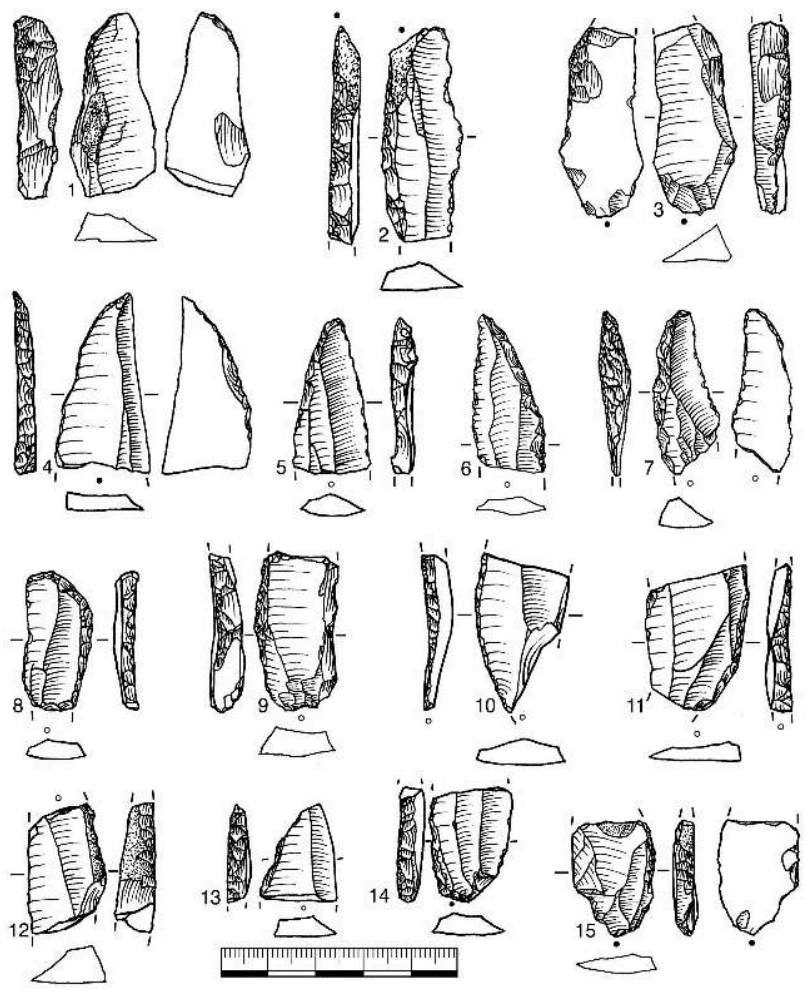

Realization: H. Würschem, Ch. Hoyer

\section{The Châtelperronian objects}

In this paper, we wish to present all the remains attributable to the Châtelperronian, with a certain probability. This work comprises objects from early excavations and recently excavated sediments, but also from the backfill from early excavations. There are also several stratified elements. We will present these remains together, as there are no grounds for presenting them subdivided into series, places or levels. A large portion of these objects were selected based on typological criteria. Our aim, beyond the presentation of the fossil directors, is also to present the technological elements (cores, debitage), probably belonging to the Châtelperronian (see Würschem 2015).

\section{The Châtelperron points}

La Verpillière I Cave has yielded 47 Châtelperron points (fig. 6-9). Two additional specimens come from cave II, which makes a total of 49 points, but the latter were not included in the analyses. Twenty-seven points come from early excavations, including 17 from the first excavations by Charles Méray (1868), seven from the surface collection and excavation by Gros (1951-1952), one from the Delporte excavation (1953-1955), one point from the Thevenot surface collection (1956-1957) and another from a non-defined excavation (Dutkiewicz 2011, Dutkiewicz \& Floss 2015). Twenty points come from

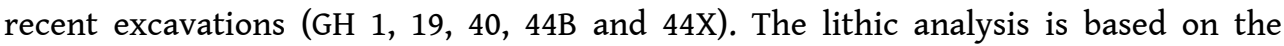
Tübingen system (Hahn 1993; Floss 2012), adopting several elements from other 
studies, such as La Grande Roche de la Plématrie at Quinçay (Vienne) (Roussel 2011, 2013, 2014; Roussel \& Soressi 2010; Roussel, Soressi and Hublin 2016), the study of the material from Grotte du Renne at Arcy-sur-Cure (Connet 2002) as well as Roc-de-Combe and de La Côte (Pelegrin 1995).

\section{Raw materials}

Most of the Châtelperron points from Germolles ( $\mathrm{n}=38,80.85 \%)$ are in flint derived from the local clays with flint from the Côte Chalonnaise. For the débitage from this site, the proportion of this type of local flint is approximately $95 \%$ throughout the Upper Palaeolithic sequence. The percentage of non-local raw materials is thus higher for the Châtelperron points $(19.15 \%)$. Two points are in pink chert, four in indeterminate flint and three in zoned Tertiary flint (fig. 8.5, fig. 9.1, 12), probably from the outcrops of Mont-lès-Étrelles in Haute-Saône, 120 km northeast of Germolles (Floss 2003) and brought to the site as finished points. This hypothesis is backed up by the absence of cores and Châtelperronian debitage for this raw material. This provenance is related to a poorly known eastern geographic extension of the Chattelperronian and also revives the question of the Châtelperronian from Trou de la Mère Clochette (see below).

\section{Dimensions}

The average width of the Chatelperron points (fig. $10 \mathrm{a}$ ) is $1.76 \mathrm{~cm} \pm 0.34$, the average thickness (fig. $10 \mathrm{~b}$ ) is $0.67 \mathrm{~cm} \pm 0.19$ and the average length of the whole points is (fig. $10 \mathrm{c}) 5.55 \mathrm{~cm} \pm 1.36$. The longest point (fig. 6.1) measures $10.73 \mathrm{~cm}$, but it is an exceptional case. The dimensions are equivalent at Quinçay where the lengths of the points are $5.18 \mathrm{~cm} \pm 1.39$ for the lower Chattelperronian $\mathrm{En}, 5.42 \mathrm{~cm} \pm 1.31$ for the middle level $\mathrm{Em}$ and $4.38 \mathrm{~cm} \pm .081$ for the upper level Ej. The width for these levels is $1.56 \mathrm{~mm}$ $\pm 0.38 ; 1.69 \mathrm{~cm} \pm 0.39$; and $1.39 \mathrm{~cm} \pm 0.26$ (Roussel, Soressi and Hublin 2016). D. Baffier (1999) defines the typical length as 4 to $6.5 \mathrm{~cm}$, indicating an extreme value of $10 \mathrm{~cm}$. At Roc-de-Combe, 52 of the 84 whole Châtelperron points measure 4.0 to $6.0 \mathrm{~cm}$ long (Pelegrin 1995).

The elongation (length-width ratio) of the whole Châtelperron points from Germolles is $2.99 \pm 0.50$ and the robustness (width-thickness ratio) is $2.82 \pm 0.86$. At Quinçay, these indices are $3.4 \pm 0.8$ and $3.1 \pm 0.9$ (level En), $3.3 \pm 0.6$ et $3.4 \pm 0.9$ (level Em) and $3.2 \pm 0.5$ et $3.2 \pm 0.7$ (level Ej) (Roussel, Soressi and Hublin 2016). At Quinçay, the straightness of the back was also measured, i.e. "on whole objects, the rectilinear portion of the back strictly perpendicular to the base of the object" (Roussel 2011 - p. 145). This procedure was applied to test the hypothesis advanced by F. Lévêque, stating that the "evolved" Châtelperron points (level Em) would be straighter than the "early or typical" points (level En) (Roussel \& Soressi 2010; Roussel 2011; Roussel, Soressi and Hublin 2016). At La Verpillière I, without subdivision into several levels, we did not take this type of measurement. The average weight of the Germolles points, measured on 10 objects, is $6.6 \mathrm{~g}$. 
Figure 10 - Dimensions of the Châtelperronian points. a) width, b) thickness, c) length of the whole artefacts.

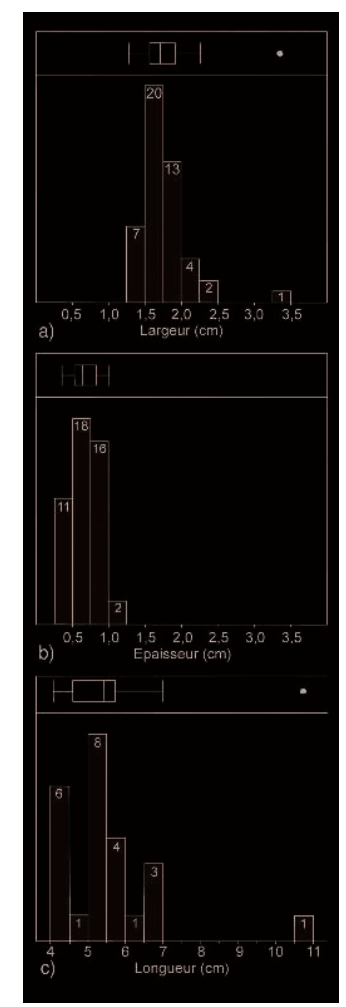

\section{Debitage and orientation}

31 All the blanks of the Châtelperron points are blades. Most often they come from unidirectional debitage (78.72\%), like at Arcy-sur-Cure (Connet 2002), but ten blades bear bidirectional debitage scars $(21.28 \%)$. The knapping techniques show high variability. Four blanks were clearly knapped with a hard hammer, eight show direct soft percussion marks and seven were knapped with soft stone. These observations are different from the Roc-de-Combe and La Côte series with a predominance of direct soft percussion (Pelegrin 1995, corrected to soft stone percussion in Pelegrin 2012).

Twenty-two of the 47 points were made on blades with an asymmetric section (Roussel 2011), which facilitated their transformation. We distinguish backed blades on an abrupt cortical facet $(n=4)$ or a crest or neo-crest $(n=6)$, or again an abrupt facet formed by a scar in orthogonal position in relation to the other dorsal removals $(n=12)$. At Quinçay, a fifth of the points represent this latter configuration (Roussel, Soressi and Hublin 2016 - p. 17).

33 As for the orientation of the active point in relation to the blank, on five objects (10.6 \%) the point is located on the proximal end and not on the distal end of the blade. At Arcy-sur-Cure, N. Connet observed 5 to $15 \%$ of this type of object, depending on the levels: "This inversion is observed when the morphology of the distal part of the blank does not allow for the transformation of the point, when it is too thick, plunging, or presents a curved profile or when it is too thin, and does not allow for the curve of the sought-after point" (Connet 2002 - p. 370). At Quinçay, the rate of this inversion is 10-15\% (Roussel 2011). 


\section{Lateralisation} the right-hand side of the retouched point is preferentially retouched (Baffier $1999-\mathrm{p}$. 60-62). At La Verpillière I, it is different. The back is on the left for 27 points (57.4 \%) and on the right for 20 (42.65\%). In Quinçay, for level En, this ratio is $52 \%$ right/ $48 \%$ left, for level Em 45\% right/ 55\% left and in the upper level Ej $75 \%$ right/ $25 \%$ left, although this latter level only contains eight Châtelperron points (Roussel 2011). At Arcy-sur-Cure, the result is similar: "The back is indifferently situated on the left or the right of the blanks" (Connet 2002 - p. 370). Still in Arcy, the back is formed by wide, regular and direct retouch. "In rare cases, the retouch is intersecting, namely when the back is too abrupt in relation to the flaked surface of the blank, which occurs especially in the last third of the tool, towards the point" (Connet 2002 - p. 369). This same observation applies to several objects from Germolles (for example fig. 6.2, 7.7 or 9.7). In Quinçay, this same phenomenon occurs where this type of retouch accentuates the offset characteristic of the point and makes it easier to control the thickness of the back (Roussel 2011 - p. 156).

\section{Impact marks}

Experimental archaeology publications describe the marks on projectile points interpreted as impact marks. These marks are also found on certain Châtelperron points (Pelegrin and Soressi 2007, 288). We identify simple fractures, splintering fractures and cone fractures beginning as flexion fractures, removing a small flake or shard (Fischer, Vemming Hansen 1984; O'Farrell 2004; O'Farrell 2005 - p. 398). We can add pseudo-burin type impact marks and crushing showing a "cluster of overlapping step scars parallel to the long axis of the tool" (Villa et al. 2009 - p. 855). Châtelperron points are often interpreted as projectile points in Châtelperronian contexts. The argument for this attribution is based on "apical shock stigmata". The four fractured Châtelperron points from Brassempouy (Abri Dubalen, Landes) (Bachellerie et al. 2011 - p. 138) and the two points with impact marks from Labeko Koba (Rios-Garaizar 2008 - p. 28) are examples of these types of marks.

At Germolles, 11 Châtelperron points bear marks identified as impact marks. There are seven cone fractures, "crushing" and three pseudo-burins (fig. 11). 
Figure 11 - Grotte de la Verpillière I, impact scars on the active distal ends of Châtelperronian points. 1: crushing, 2-8: cone fracturing, 9-11: pseudo-burin fracturing.

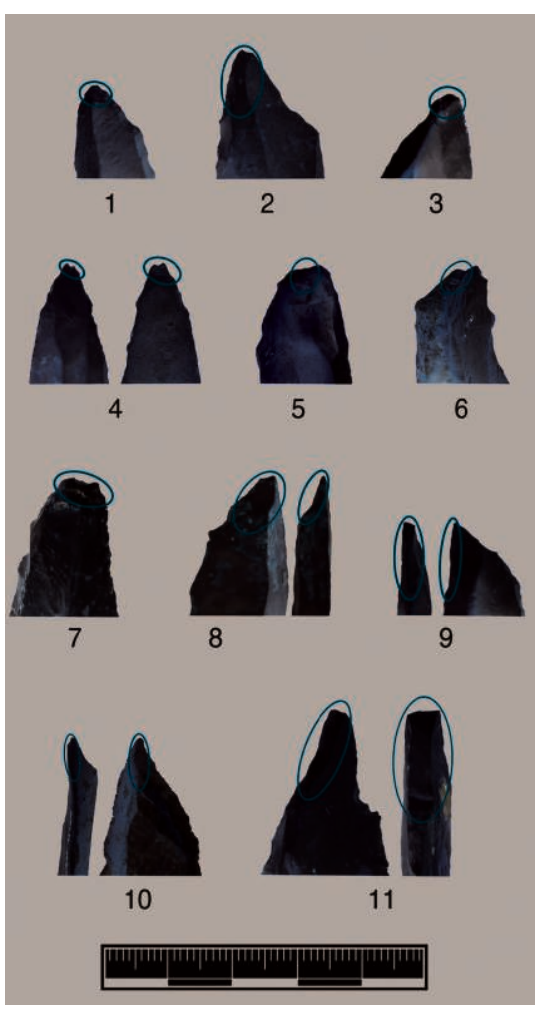

Realization: H. Würschem, Ch. Hoyer

\section{Other retouched elements}

Other types of Châtelperronian lithic tools, such as end scrapers, end scrapers "(...) on large thick flakes with an extensive end scraper arc" (Demars and Laurent 1989 - p. 154) or on "invasive laminar flakes" (Roussel 2011 - p. 108) (see also (Roussel 2011; RiosGaraizar et al. 2012; Baillet, Bachellerie and Bordes 2014; Roussel, Soressi and Hublin 2016) with "either parallel or subparallel laminar scars" (...), "or previous invasive flake scars (...)" (Roussel 2011 - p. 108), have not yet been discovered at Germolles, but we cannot rule out their presence before a more meticulous sorting of a large batch of flakes from the site.

\section{Abri Audi type knives}

Abri Audi type knives are present during the Acheulean tradition Mousterian, but they also appear in small quantities during the Châtelperronian (Bordes 1953; SonnevilleBordes and Perrot 1956; Roussel 2011; Bolus 2012). In Germolles, three objects correspond to the definition of these knives (fig. 12.1, 2, 5), to which we can add three non-retouched blanks with a natural back (fig. 12.3, 4, 6). 
Figure 12 - Grotte de la Verpillière I, backed knives, type Abri-Audi knife: 1: Gros test pits, 2: Méray excavations, 5: Tübingen excavations. Elongated, naturally backed flakes with the shape of a knife: 3, 4, 6: Méray excavations. Crested blades resembling Châtelperronian points: 7-9 : Tübingen excavations.

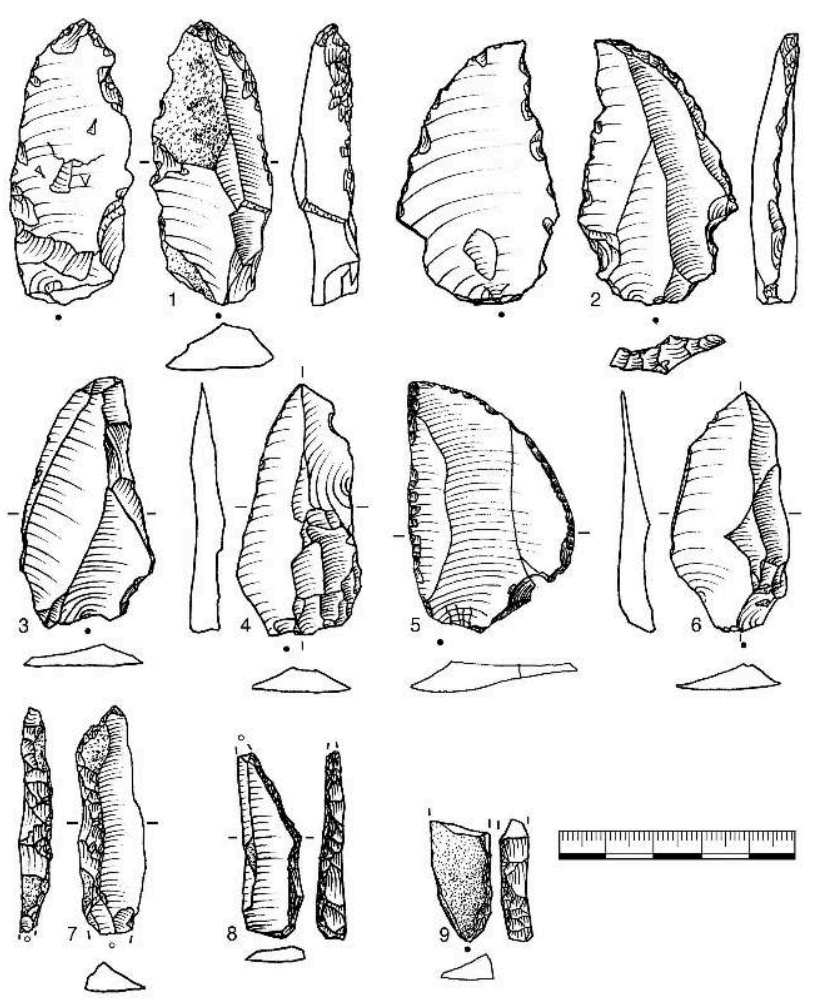

Realization: H. Würschem, Ch. Hoyer

\section{Cores}

Apart from fossiles-directeurs and their emblematic components, Châtelperron points, we also wish to highlight the question of the presence of on-site debitage. The high number of points $(n=44)$, which is probably only a small part of the total for the site, points to a relatively consistent Châtelperronian occupation. Nonetheless, the presence of debitage strengthens the human settlement aspect of the site. It is mainly from a reworked context, and required a comparative study with contemporaneous series, preferably from Burgundy (Grotte du Renne, Connet 2002), but also from the west of the Massif central (Quinçay, Roussel 2013; Roc-de-Combe and La Côte, Pelegrin 1995).

At Quinçay, M. Roussel defines three groups of cores, cores worked on two surfaces, three surfaces and a single narrow surface. They are characterized by a debitage rhythm in two phases (...) "on a laminar volume with an angular section" (Roussel 2013 - p. 236), beginning on a ridge and extending first onto one surface and then onto the other. The surfaces are worked separately, each representing an independent volume from the previous one (Roussel, Soressi and Hublin 2016).

41 Nelly Connet defines five groups of cores including numerous sub groups, differentiated by their volume and the resulting blanks. Groups I, II and III are particularly important for the production of Châtelperronian blades. Group I includes cores with uni- or bi-directional blades, with a natural or prepared crest. The sides of the core can be prepared or not. Production begins from the crests and affects the main 
surface, but can also overrun onto the sides (Connet 2002 - p. 40-42). Group II also includes cores with uni- or bi-directional blades, but laminar production runs over the sides and invades three quarters of the core periphery. Group III also includes cores with uni- or bi-directional blades, but with two adjoining sides. The first is the back of the core which is only slightly prepared or non-prepared. The second is the debitage surface, but is only slightly knapped. We only rarely find cases with two knapped surfaces

42 Jacques Pelegrin distinguishes seven types of cores (1995 - p. 115-116). First of all, he distinguishes cores knapped on a narrow surface, a wide surface or a wide and narrow surface. Secondly, he takes the striking platforms into consideration. Group 1 thus contains cores with two opposed striking platforms. The debitage covers the narrowest part of the transverse part of the core. This core is prismatic. Group 2 includes cores with two opposed striking platforms. Debitage preferentially covers the widest part of the transverse part of the core. This core has a prismatic aspect and is flat when the core is very wide. Group 3 cores consists of cores with two opposed striking platforms. Debitage occurs on a narrow surface and then on a wide surface. This core is also prismatic. Groups 4, 5 and 6 are similar to the groups described above, but do not have a striking platform. Group 7 from Roc-de-Combe is rare and includes cores with two opposed striking platforms and two separate debitage surfaces.

The production of flakes in the Châtelperronian only plays a subordinate, or very secondary role, in relation to blade production. At Quincay, among the 452 studied cores, 363 are blade cores, 51 are bladelet cores and only nine are considered as separate flake cores (Roussel, Soressi and Hublin 2016). At grotte du Renne in Arcy-surCure, the rate of flake cores is between 16 and $23 \%$, decreasing towards the upper levels. There are flat unifacial centripetal cores and discoidal cores (Connet 2002 - $p$. 387). At Germolles, no Châtelperronian flake cores have been found in situ.

Altogether, we identified 11 cores corresponding to the criteria described above for Châtelperronian cores. First of all, we identified two cores (fig. 13.1, 11) with only one striking platform with the main deibtage on the wide of the core (Pelegrin's group 5, core on one surface according to Roussel). Other cores use this same principle (fig. 13.3, $5,7)$ but have two striking platforms (Pelegrin group 2). 
Figure 13 - Grotte de la Verpillière I, cores. 1, 3, 5, 7, 9-11: Méray excavations, 2: Pelatin collection, $4,6,8$ : Tübingen excavations.

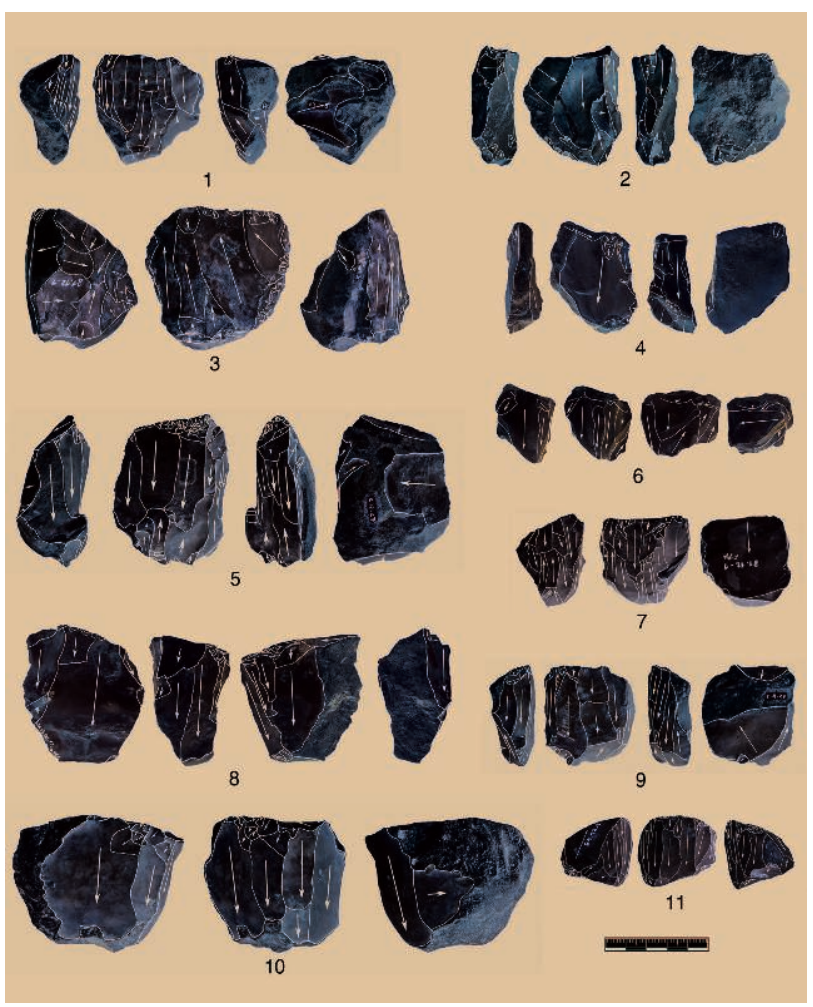

Realization: H. Würschem, Ch. Hoyer

There are also cores worked on three surfaces, two of which are wide and one narrow (fig. 13. 8), with the scar of an invasive laminar flake. According to Roussel (2011 - p. 271, fig. 5.31) they are due to an "(...) extraction of a flake as wide as long on the widest surface of the volume (...)". In most cases, it extends over the whole length and width of this surface and can even sometimes extend beyond it".

We also note the presence of flat cores, with a striking platform, worked on a wide surface, then on a narrow surface (fig. 13.2, 4, 9, 10) (Pelegrin group 6, core with two surfaces according to Roussel). Two cores (fig. 13.2, 4) present the remains of an invasive laminar flake. They are similar to some of the cores from Arcy-sur-Cure (Connet 2002, fig. 30.1), Roc-de-Combe (Pelegrin 1995, fig. 56) and La Grande Roche de la Plématrie (Roussel 2013, fig. 1c).

We also find cores knapped on a wide surface and a narrow surface, with two striking platforms (fig. 13. 6) (Pelegrin group 3, cores with two surfaces according to Roussel).

The cores from Germolles are more difficult to compare to those from Arcy-sur-Cure as the latter were categorized according to numerous criteria. Several pieces (fig. 13.1, 2, 4) are related to group III, some have a lateral crest like for group I (fig. 13, 3) and others (fig. 13.6, 7, 10,11) are related to group II.

Altogether, five cores from Germolles display a wide knapping surface and five others were knapped on a wide surface then a narrow surface. A core was knapped on three surfaces. When we compare them with the Pelegrin groups, three cores from Germolles appear to be group 2 cores (bidirectional, one surface), one belongs to his group 3 
(bidirectional, two surfaces), two to his group 5 (unidirectional, one surface) and four to his group 6 (unidirectional, two surfaces).

One core from Germolles in particular (fig. 13.8) shows similarities with what was observed for the cores from Arcy, Quincay and the sites of J. Pelegrin, namely because of the presence of an invasive laminar flake scar.

Three of the illustrated cores (fig. 13.6,7,9,11) are small in size with narrow laminar removal scars. We cannot identify a separate bladelet production, proposed by Roussel, Soressi and Hublin for Quinçay (2016). At Germolles, the cores are heavily worked and are characterized by the presence of bladelet and blade scars (metric width criteria). No Châtelperronian cores are only used for bladelet production.

Four of the illustrated cores have two striking platforms (fig. 13.3,5,6 and 7). For two of them (fig. 13.3 and 7), the second striking platform is used mainly to correct the core volume. One core is highly worked (fig.13.6) and it is not possible to observe any separate laminar production from the second striking platform. Only one core (fig. 13.5) seems to be knapped from the opposing striking platform, before the last series of blades was removed from the main striking platform. The other cores were knapped unidirectionally and only have one striking platform. At Quinçay, cores with two striking platforms are frequent. But the series of blades remain unidirectional, as both striking platforms have separate knapping surfaces (Roussel, Soressi and Hublin 2016). At Germolles, the cores are too worked to be able to identify this type of knapping.

\section{Non-retouched knapping products}

53 We also selected blades probably belonging to the Châtelperronian corpus. We focused on three groups of blanks previously defined as blanks on points and in particular, on pieces with a dorsal scar with an orthogonal orientation in relation to the others. This type of blade is very sought after, as it facilitates the transformation of the back (Roussel 2013; Roussel, Soressi and Hublin 2016). At Quinçay, this type of blade represents $20 \%$ of the laminar products. It is the product of a debitage in "two stages" or "three stages", and revolves around the transition between working from one surface to the other.

Forty-one blades correspond to the defined criteria (fig. 14, 15). Thirty-five are in local flint, one in pink chert, four in non-determined flint and one in Tertiary flint. Eleven pieces bear a cortical back, for 16 the back is formed by a ridge and 14 blades bear an orthogonal scar.

These blades have an average width of $1.71 \mathrm{~cm} \pm 0.43$, a thickness of $0.66 \mathrm{~cm} \pm 0.23$ and a length of $4.60 \mathrm{~cm} \pm 1.14$ (whole pieces $\mathrm{n}=15$ ). At Quinçay, the blades measure on average $5.1 \mathrm{~cm} \pm 1.5$ long and $1.8 \mathrm{~cm} \pm 0.5$ wide (Roussel 2013). The elongation at Germolles is $2.68 \pm 0.62$ and the robustness $2.79 \pm 1.01$. 
Figure 14 - Grotte de la Verpillière I, semi-cortical blades: 1: Méray excavations, 2-12: Tübingen excavations. Blades with an orthogonal scar. 9: Méray excavations, 13-18: Tübingen excavations.

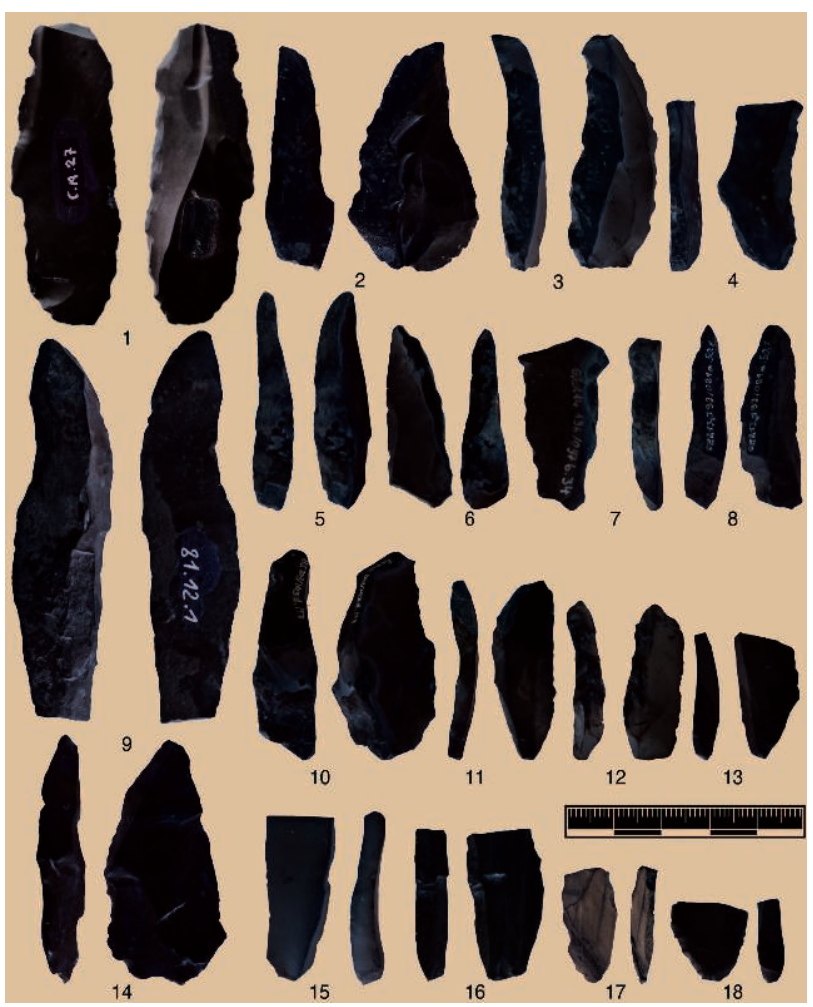

Realization: H. Würschem, Ch. Hoyer 
Figure 15 - Grotte de la Verpillière I, blades with an orthogonal scar. 1, 9: Méray excavations, 2-6: Tübingen excavations. Crested blades: $7,8,10,11,13,15-20$ : Tübingen excavations, 12, 14: Gros excavations.

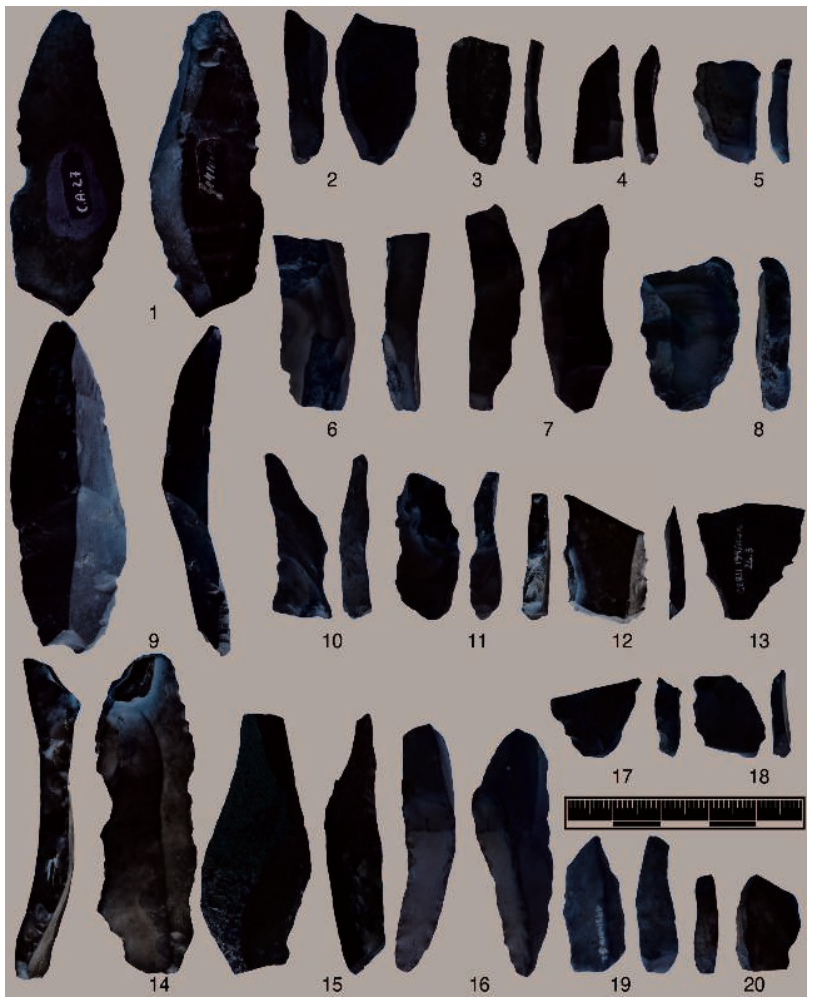

Realization: H. Würschem, Ch. Hoyer

Châtelperron points (fig. 14,7-9), even without transformation of the back by abrupt retouch. These pieces are almost Châtelperron points and seem to be perfectly adapted to use, but we prefer not to include them in the corpus of points: "In the same way, the production of blades with an asymmetric section leads us to question the direct use of these Châtelperronian products, which can be functionally considered as backed pieces, in the same way as éclats débordants Levallois which were used without retouch in some cases" (Roussel 2011 - p. 454, citing Beyries and Boëda 1983). a vast extension of objects inside and on the terrace of the present-day cave. This observation also points to a significant Châtelperronian occupation. The remains from the recent excavations were mapped every square metre, whereas those from the early excavations were only plotted by layer or level.

\section{The Châtelperronian in southern Burgundy and in Franche-Comté}

The geographic position of Germolles at the eastern limit of the known distribution of the Châtelperronian (Bosinski 1987; Floss 2003; Ruebens, Mc Pherron and Hublin 2015) creates a very interesting paleogeographic position, near the surrounding regions, like for example the Swabian Jura, where there is a very early Aurignacian (Higham et al. 
2012). This said, we carried out a study on a possible Chatelperronian context of the site of Germolles in this region of the Saone basin (see Floss 2003).

\section{Le Trou de la Mère Clochette}

59 The most interesting site in this respect is by far le Trou de la Mère Clochette at Rochefort-sur-Nenon (Jura) (R. Desbrosse 1976 - p. 1351), 85 km northeast of Germolles. This site was excavated by J. Feuvrier from 1905 to 1909, and subsequently by A. Guichon (Trou aux Renards) and R. Desbrosse, then recently by L. Brou, who focused on the characterization and the dating of the Aurignacian (Brou 1997; Szmidt, Brou and Jaccottey 2010). We also distinguish a "yellow series" in good quality flint from the early excavations, characterized by retouched backs. There is no convincing stratigraphy, but the chronological attribution of this series is based on a technological and especially typological characterization and fluctuates between the Chateperronian and the Gravettian. Jean Combier (1955 - p. 603) considered the industry to be typologically intermediate between Peyrony's I and IV, with backed blades "which deserve to be categorized under a different name". R. Desbrosse (1982 - p. 107) argued clearly for the existence of the early Perigordian on account of the presence of "many retouched backed knives" (Desbrosse 1982, fig. 9-11). There are in fact no less than 35 backed retouched points which have all the elements for a Châtelperronian attribution (see also Desbrosse 1984 - p. 79). Once again, it is J. Combier (1989- p. 274) who describes the Aurignacian of this site as a mixed series with elements with Châtelperronian affinities. In 1990, this same author (Combier 1990 - p. 270) notes the presence of about "ten indisputable Châtelperron backed knives", but he maintains that these elements could be incorporated with the Aurignacian.

Laurent Brou (Brou 1997 - p. 17) refers to a "Perigordian with a still poorly characterized facies". The series in question contains 738 lithic elements, including 361 retouched pieces. The author wavers between an attribution to the evolved Châtelperronian and the Gravettian (Brou 1997 - p. 17). In recent works, L. Brou (2009 p. 70) describes the site as one of the rare sites of the region recording the existence of the Chatelperronian and the Aurignacian. The dilemna arises from the fact that the series in question, particularly the backed points, are typologically similar to the Châtelperronian and not the Gravettian, but an unclear indication in the excavation notebooks of Jules Feuvrier seems to indicate the stratigraphic position of this series above the Aurignacian (Brou 1997 - p. 19). We are in a position to add an argument: there are three points in the Châtelperronian series from Germolles in Tertiary flint from Mont-lès-Étrelles, an outcrop immediately beside le Trou de La Mère Clochette (see also Floss 2003, 280). This element swings us in favour of a Châtelperronian series, which extends the distribution area of this complex in an easterly direction.

\section{Other Châtelperronian markers in the region}

61 The other markers of Châtelperronian presence in this region come from the Côte chalonnaise but are mainly made up of isolated remains. 
62 At Saint Vallerin, $20 \mathrm{~km}$ south of Germolles, near the coastal ledge, J.-N. Blanchot (unpublished, not dated, p. 20) vaguely describes a small series of artefacts from a canal leading onto a cavity. The circumstances of this discovery remain mysterious, but we have some ideas as to what happened. The series was handed over to Jean Combier (oral communication 2014) and very briefly to Harold Floss and includes Châtelperron points.

Chenoves, located several kilometres from Saint Vallerin, comprises several rich and complex sites, near flint-bearing clays. The sites were prospected by Abbot Guillard and contain several Châtelperronian elements (Guillard 1959 - p.13; see also Combier 1959 p.124) (station Carrouge/ rue Cataux). During the course of our study of the collections from Musée Denon at Chalon-sur-Saône, we identified a Châtelperronian point and an Abri Audi type knife (see also Herkert et al. 2015 - p.160).

64 At Saint Aubin, several kilometres north of Germolles, but in Côte d'Or, Joly (1959 - p. 98, fig. 7) described two Châtelperron points from Abri Virely, one of which was whole and the other fragmented (see also Floss 2003 - p. 281; Floss et al. 2013 b - p-. 336). René Desbrosse (1982 - p. 106, fig. 5) included this site in the corpus of Châtelperronian sites in the east of France, he drew these elements differently and changed their orientation. Jean Combier (1990 - p. 270) mentioned, beside the curved backed knives, a set of very narrow and regular blades, with a rectilinear back. He refuted the Châtelperronian attribution of this series and assigned it to the Aurignacian (Combier 1990 - p. 277). Recently, A. Desbrosse and J.-B. Peyrouse managed to find these abandoned sites.

At Saint-Désert, slightly south of Germolles, O. and A.-C. Gros (2005 - p. 169) described an abundant lithic industy in the zone between Maison-Dieu and the village, containing a Châtelperron point, according to L. Bonnamour (see also Floss 2003; Floss et al. 2013 b - p. 336). Recently, we found this artefact in the Musée Denon collections in Chalonsur-Saône.

The site of Solutré is a specific case. Jean Combier (1956; 1989 - p. 274) mentions, for the deep levels, made up of red gravel, for example for trench E from 1922, backed knives similar to Châtelperron points and since this publication $(1956$ - p. 198, 202), he includes Solutré in the "atypical lower Perigordian" corpus (see also Floss et al. 2013 b p. 335, fig. 2).

Finally, we also wish to point out Folatière Cave at Culles-les-Roches and the open-air site of Saint-Martin-sous-Montaigu, where several pieces could be related to the Châtelperronian.

We are aware that most of these artefacts are isolated and have no stratigraphic context. They are only related to the Châtelperronian by their typological aspect. Nonetheless, Rochefort-sur-Nenon and also Saint-Vallerin could represent more important occupations. Therefore, the Châtelperronian occupation of Germolles might not be an isolated case but could be part of a genuine area of Châtelperronian occupation in southern Burgundy. 


\section{Bibliographic references}

ARMAND-CALLIAT L. 1950 - Catalogue des collections archéologiques : menus objets divers des collections orientales et de la salle Niepce. Chalon-sur-Saône : R. Simonin, 100p.

BACHELLERIE F. 2011 - Quelle unité pour le Châtelperronien? Apport de l'analyse taphonomique et techno-économique des industries lithiques de trois gisements aquitains de plein air: le Basté, Bidart (Pyrénées-Atlantiques) et Canaule II (Dordogne). Bordeaux : Université de Bordeaux I, 2011. Thèse de doctorat, 441p.

BACHELLERIE F., BON F., DESCHAMPS M., EIZENBERG L., HENRY-GAMBIER D., MOURRE V., NORMAND CH., PELEGRIN J., PRIMAULT J., SCANDIUZZI R., THIÉBAUT C. 2011 - Archaeological signatures of hunting activities applied to comparisons of Mousterian, Châtelperronian and Aurignacian industries in the Pyrenees: the nature of hunting tools and site functions. In: F. Bon, S. Costamagno, N. Valdeyron (Eds.), Hunting Camps in Prehistory. Current Archaeological Approaches, Proceedings of the International Symposium (may 13-15 2009). Université Toulouse II, Le Mirail, p. 131-167 (Pal@ethnology, N³).

BADER G. 2011 - Stratigraphische Befunde aus dem Paläolithikum der Höhle Grotte de La Verpillière I in Germolles (Saône-et-Loire, Frankreich). Tübingen : Eberhard Karls Universität Tübingen, 2011. Thèse de bachelor, 50p.

BAFFIER D. 1999 - Les derniers Néandertaliens. Le Châtelperronien. Paris : La maison des roches (Histoire de la France préhistorique), 113p.

BAILLET M., BACHELLERIE F., BORDES J.-G. 2014 - Enquête autour d'un outil : approche technoéconomique, fonctionnelle et expérimentale des grattoirs châtelperroniens de Canaule II (Creysse, Dordogne, France). Paleo, 25, p. 7-36.

BEYRIES S., BOËDA E. 1983 - Étude technologique et traces d'utilisation des 'éclats débordants' de Corbehem (Pas-de-Calais). Bulletin de la Société Préhistorique française, 80, 9, p. 275-279.

BLANCHOT J.-N. non daté - Chenoves, St. Vallerin, le goût Aurignacien. 22p.

BOLUS M. 2012 - Messer mit Rücken. In: FLOSS H. (Ed.), Steinartefakte vom Altpaläolithikum bis in die Neuzeit. Tübingen : Kerns Verlag, p. 287-292.

BORDES F. 1953 - Essai de classification des industries „moustériennes”. Bulletin de la Société préhistorique française, 50, 7-8, p. 457-466.

BOSINSKI G. 1987 - Die große Zeit der Eiszeitjäger. Europa zwischen 40.000 und 10.000 v. Chr. 5. Theodor Mommsen-Vorlesung 1986. Mainz, Römisch-Germanisches Zentralmuseum, p. 3-139 (Jahrbuch des Römisch-Germanischen Zentralmuseums, ${ }^{\circ} 34$ ).

BREUIL H. 1909 - L'Aurignacien présolutréen. Épilogue d'une controverse. Revue préhistorique, 4, 8-9, p. 5-46.

BREUIL H. 1911 - Etudes de morphologie paléolithique : I. L'industrie de la grotte de Châtelperron (Allier) et d'autres gisements similaires. Revue de l'Ecole d'Anthropologie, 21, p. 29-40 et p. 66-76.

BROU L. 1997 - L'industrie aurignacienne du « Trou de la Mère Clochette » à Rochefort-surNenon, Jura. Présentation des données. In : A. Thévenin, A. Villes (Eds.), Le paléolithique supérieur 
de l'Est de la France : de l'Aurignacien à l'Ahrensbourgien. Actes du colloque de Chaumont (17-18 octobre 1994). Reims, Société Archéologique Champenoise, p. 15-35 (Mémoire de la Société Archéologique Champenoise, $\mathrm{n}^{\circ}$ 13, suppl. 2).

BROU L. 2009 - De l'Aurignacien au Trou de la Mère Clochette à Rochefort-sur-Nenon. In : L. Jaccottey, L. Brou (Eds.), Les recherches de Julien Feuvrier (1851-1936), historien, archéologue, archiviste et conservateur du musée : Catalogue d'exposition "Dole et sa région, de la Préhistoire au 18e siècle ». Musée des Beaux-Arts de Dole, 13 mars-24 mai 2009, sous la direction de Jean-Luc Mordefroid, Jaccottey L. \& Brou L. (Commissariat scientifique). Dole, Association des Amis du musée du Jura, p. 65-71.

CHIOTTI L. 2003 - Les productions lamellaires dans l'Aurignacien de l'abri Pataud, Les Eyzies-deTayac (Dordogne), Gallia préhistoire, 45, p. 113-156.

COMBIER J. 1955 - Observations complémentaires sur le Périgordien. Bulletin de la Société préhistorique française, 52, 9, p. 602-603.

COMBIER J. 1956 - Solutré. Les fouilles 1907 à 1925. Travaux du Laboratoire de Géologie de la faculté des Sciences de Lyon, nouvelle série 2. Lyon.

COMBIER J. 1959 - Mellecey. Informations archéologiques. Gallia Préhistoire, 2, 120-121, p. 124.

COMBIER J. 1989 - Aurignacien et Périgordien dans l'Est de la France. In : J.-P. Mohen (Ed.), Le temps de la Préhistoire I. Paris : Faton, p. 274-275.

COMBIER J. 1990 - De la fin du Moustérien au Paléolithique supérieur- les données de la région Rhodanienne. In : C. Farizy (Ed.), Paléolithique moyen récent et Paléolithique supérieur ancien en Europe. Colloque International de Nemours (9-11 mai 1988), p. 267-277 (Mémoires du Musée de Préhistoire d'Ile-de-France, $\mathrm{n}^{\circ} 3$ ).

CONNET N. 2002 - Le Châtelperronien. Réflexions sur l'unité et l'identité techno-économique de l'industrie lithique. L'apport de l'analyse diachronique des industries lithiques des couches Châtelperroniennes de la grotte du Renne à Arcy-sur-Cure (Yonne). Lille : Université de Lille I, 2002. Thèse de doctorat, 445p. DELOZE V., DEPAEPE P., GOUÉDO, J.-M., KRIER V., LOCHT J. 1994 - Le Paléolithique dans le nord du Senonais (Yonne). Contexte géomorphologique, industries lithiques et chronostratigraphie. documents d'Archaeologie Française, Vol. 47. Maison des sciences de l'Homme, Paris.

DELPORTE H. 1953 - L'industrie de Châtelperron et son extension géographique. In : Congrès Préhistorique de France. Compte-rendu, XIVème session, Strasbourg-Metz, p. 233-249.

DELPORTE H. 1955 - De la complexité du fait paléolithique à la lumière de fouilles nouvelles (Châtelperron et Germolles). Pallas, 3, Faculté des lettres, Toulouse, p. 153-162.

DEMARS P.-Y., LAURENT P. 1989 - Types d'outils lithiques du paléolithique supérieur en Europe. Paris: Centre National de la Recherche Scientifique (Cahiers du Quaternaire, $n^{\circ} 14$ ).

DESBROSSE R. 1976 - Le Paléolithique supérieur dans le Jura et en Franche-Comté. La Préhistoire Française I, 2, Paris : CNRS Éditions, p. 1348-1357.

DESBROSSE R. 1982 - Sites périgordiens en grottes dans le quart nord-est de la France. In: Aurignacien et Gravettien en Europe. Liège : Université de Liège, p. 105-122 (Etudes et Recherches Archéologiques de l'Université de Liège, $\mathrm{n}^{\circ}$ 13: 2).

DESBROSSE R. 1984 - Périgordien et Aurignacien anciens de la Mère Clochette à Rochefort-surNenon (Jura). In : Éléments de préhistoire et protohistoire européenne. Hommages à Jacques-Pierre Millotte. Paris : Belles Lettres. Annales littéraires de l'université de Besançon, p. 71-95 (Série archéologie $n^{\circ} 32$ ). 
DESBROSSE R., TEXIER P. J. 1973 - Les silex de Germolles dans la collection Jeannin. La Physiophile, 79, p. 64-70.

DESBROSSE R., KOZLOWSKI J. K., ZUATE Y ZUBER, J. 1976 - Prondniks de France et d'Europe Centrale. L'Anthropologie, 80, 3, p. 431-448.

DUTKIEWICZ E. 2011 - Die Grotte de La Verpillière I - 150 Jahre Forschungsgeschichte. Die Aufarbeitung und Auswertung der Altgrabungen des paläolithischen Fundplatzes Germolles (Commune de Mellecey, Saône-et-Loire, Frankreich). Tübingen: Eberhard Karls Universität Tübingen, 2011. Mémoire de Maîtrise, 179p.

DUTKIEWICZ E., FLOSS H. 2015 - La grotte de La Verpillière I à Germolles, site de référence paléolithique en Bourgogne méridionale. Historique des 150 ans de recherches. La Physiophile, 162, p. 13-32.

FISCHER A., VEMMING HANSEN P., RASMUSSEN P. 1984 - Macro and Micro Wear Traces on Lithic Projectile Points. Experimental Results and Prehistoric Examples. Journal of Danish Archaeology, 3, p. 19-46.

FLOSS H. 2003 - Did they meet or not? Observations on Châtelperronian and Aurignacian Settlement Patterns in Eastern France. In: J. Zilhao, D'Errico F. (Ed.), The Chronology of the Aurignacian and of the Transitional Technocomplexes : Dating, Stratigraphies, Cultural Implications. Actes du symposium 6.1 du Congress XIV de l'UISPP (2-8 Septembre 2001), Lisbonne: Instituto Português de Arqueologia, p. 273-287, (Trabalhos de arqueologia, $n^{\circ} 33$ ).

FLOSS H. 2005 - Das Ende nach dem Höhepunkt. Überlegungen zum Verhältnis Neandertaler anatomisch moderner Mensch auf Basis neuer Ergebnisse zum Paläolithikum in Burgund. In: N. J. Conard, S. Kölbl, W. Schürle (Eds.), Vom Neandertaler zum modernen Menschen, Ostfildern : Thorbecke, p. 109-130.

FLOSS H. et al. 2006 à 2016 - Rapports de fouilles programmées des grottes de La Verpillière à Germolles (commune de Mellecey, Saône-et-Loire), DRAC, S.R.A. Bourgogne, Dijon.

FLOSS H., DUTKIEWICZ E., FRICK J.A., HOYER C.T. 2013 - Le Paléolithique supérieur ancien en Bourgogne du sud. In : P. Bodu, L. Chehmana, L. Klaric, L. Mevel, S. Soriano, N. Teyssandier (Eds.), Le Paléolithique supérieur ancien de l'Europe du Nord-Ouest: Réflexions et synthèses à partir d'un projet collectif de recherche sur le centre et le sud du Bassin parisien. Actes du colloque de Sens (15-18 avril 2009), Paris : Société Préhistorique Française, p. 331-350.

FLOSS H., HOYER C.T., HECKEL C.E., TARTAR É. 2015 a - The Aurignacian in Southern Burgundy. P@léthnologie, 7, p. 165-187.

FLOSS H., HOYER C.T., PAUTRAT J.-Y. 2015 b - De Néanderthal à Cro-Magnon. Un PCR, consacré au Paléolithique en Bourgogne Méridionale, In: S.R.A Bourgogne, ARTeHIS (Eds.), Actes de la Journée Regionale d'Archéologie. (24 mai 2014). Dijon, Imprimerie Chaumeil, p. 44-50.

FRICK J.A., FLOSS H. 2017 - Analysis of bifacial elements from Grottes de La Verpillière I \& II (Germolles, France). Quaternary International, 428, p. 3-25. doi:10.1016/j.quaint.2015.10.090.

GÖTZ T. 2013 - Das Jungpaläolithikum der Grotte de La Verpillière II (Burgund, Frankreich). Tübingen : Eberhard Karls Universität Tübingen, 2013. Thèse de bachelor, 55 p.

GROS A.-C. 1958 - La Grotte de La Verpillière à Germolles (Saône-et-Loire). L'Eduen, 8, p. 7-8.

GROS A.-C. 2007 - Henri Delporte et les fouilles de la grotte de Germolles (Saône-et-Loire). In : R. Desbrosse, A. Thévenin (Eds.), Arts et cultures de la préhistoire, Paris : CTHS, p. 159-167 (Documents préhistoriques, $\left.\mathrm{n}^{\circ} 24\right)$. 
GROS O., GROS A.-C. 2005 - Le Chalonnais préhistorique. Collections du Musée de Chalon-sur-Saône. Chalon-sur-Saône. Chalon-sur-Saône.

GUILLARD E. 1954 - Une station aurignacienne inédite à Germolles. Mémoires de la Société d'Histoire et d'Archéologie de Chalon-sur-Saône, 33, p. 129-138.

GUILLARD E. 1959 - Note sur les stations et vestiges préhistoriques de la Côte Chalonnaise trouvés à Chenoves, Saules et à l'est de Culles-les-Roches. La Physiophile, 50, p. 2-16.

HAHN J. 1993 - Erkennen und Bestimmen von Stein- und Knochenartefakten. Einführung in die Artefaktmorphologie. Tübingen : Institut für Urgeschichte (Archaeologica Venatoria, $\mathrm{N}^{\circ} 10$ ).

HARROLD F. B. 1986 - Une réévaluation du Châtelperronien. Bulletin de la Société Préhistorique Ariège-Pyrnénées, 41, p. 151-169.

HECKEL C., HIGHAM T.F.G., HOYER C.T., FLOSS H. 2016 - Radiocarbon dating of Verpillière I and II. In: Project Collectif de Recherche: Le Paléolithique supérieur ancien en Bourgogne méridionale. Genèse, chronologie et structuration interne, évolution culturelle et technique. Raport anuell 2015. Abteilung für Ältere Urgeschichte und Quartärökologie, Service Régional d'Archéologie Bourgogne, Tübingen, Dijon, p. 30-37.

HERKERT K., SIEGERIS M., CHANG J.-Y., CONARD N. J., FLOSS H. 2015 - Zur Ressourcennutzung später Neandertaler und früher moderner Menschen. Fallbeispiele aus dem südlichen Burgund und der Schwäbischen Alb. Mitteilungen der Gesellschaft für Urgeschichte, 24, p. 141-172.

HIGHAM T., BASELL L., JACOBI R., WOOD R., BRONK RAMSEY C., CONARD N. J. 2012 - Testing models for the beginnings of the Aurignacian and the advent of figurative art and music: The radiocarbon chronology of Geißenklösterle, Journal of Human Evolution, 62, p. 664-676.

HOYER C.T., HUBER N., LITZENBERG R., FLOSS H. 2016 - Rapport de Fouille 2013-2015. In: Fouilles programmés pluriannuelles aux sites paléolithiques des Grottes de La Verpillière I \& II à Germolles, commune de Mellecey (Saône-et-Loire). Rapport annuel 2015, rapport pluriannuel 2013 à 2015. Abteilung für Ältere Urgeschichte und Quartärökologie, Service Régional d'Archéologie Bourgogne, Tübingen, Dijon, p. 86-133.

HUBLIN J.-J., TALAMO S., JULIEN M., DAVID F. CONNET N., BODU P., VANDERMEERSCH B., RICHARDS M.P. 2012 - Radiocarbon dates from the Grotte du Renne and Saint-Césaire support a Neandertal origin for the Châtelperronian, PNAS, 109 : 46, p. 18743-18748.

JOLY J 1959 - St. Aubin. Gallia Préhistoire, 2, p. 96-98.

KREMMER A. 2015 - Die Lamellen aus dem GH1 der paläolithischen Fundstelle Grotte de La Verpillière I bei Germolles, Burgund. Eine statistische und typologische Auswertung. Tübingen : Eberhard Karls Universität Tübingen, 2015. Thèse de bachelor, $92 \mathrm{p}$.

LITZENBERG R. 2015 - Materialübergreifende Analyse des GH 16 der Grotte de La Verpillière I in Germolles, Gemeinde Mellecey (Saône-et-Loire, Frankreich). Tübingen : Eberhard Karls Universität Tübingen, 2015. Thèse de bachelor, $97 \mathrm{p}$.

MÉRAY CH. 1869 - L’âge de la Pierre à Germolles - Matériaux d'archéologie et d'histoire. Chalon sur Saône, p. 83-86.

MÉRAY CH., CHABAS F. 1876 - Compte rendu des fouilles de la caverne de Germolles et notes additionnelles. Mémoires de la société d'histoire et d'archéologie de Chalon-sur-Saône, 6, IIe partie, p. 251-266. 
O'FARRELL M. 2004 - Les pointes de la Gravette de Corbiac (Dordogne) et considérations sur la chasse au Paléolithique supérieur ancien. In : Approches fonctionnelles en Préhistoire. Actes du XXV Congrès Préhistorique de France, Nanterre, 24-26 novembre 2000, p. 121-138.

O'FARRELL M. 2005 - Étude préliminaire des éléments d'armature lithique de l'aurignacien ancien de Brassempouy. In: F. Le Brun-Ricalens, J.-G. Bordes, F. Bon (Eds.), Productions lamellaires attribuées à l'Aurignacien : Chaînes opératoires et perspectives technoculturelles. XIVe congrès de l'UISPP, Liège (2-8 Septembre 2001). Luxembourg, Musée national d'Histoire et d'Art, p. 395-412 (ArchéoLogiques, $\mathrm{n}^{\circ} 1$ ).

PELEGRIN J. 1995 - Technologie Lithique. Le Châtelperronien de Roc-De-Combe (Lot) et de La Côte (Dordogne). Paris: CNRS Éditions (Cahiers du Quaternaire, $\mathrm{n}^{\circ} 20$ ).

PELEGRIN J. 2000 - Les techniques de débitage laminaire au Tardiglaciaire : critères de diagnose et quelques réflexions. In : B. Valentin, P. Bodu et M. Christensen (Eds.), L'Europe centrale et septentrionale au Tardiglaciaire. Confrontation des modèles régionaux de peuplement. Actes de la tableronde de Nemours, (mai 1997). Nemours, APRAIF, Mémoire du Musée de Préhistoire d'Ile-deFrance, 7, p. 73-86

PELEGRIN J. 2012 - Sur les débitages laminaires du Paléolithique supérieur. In : F. Delpech et J. Jaubert (Eds.), François Bordes et la Préhistoire. Colloque international François Bordes, Bordeaux (22-24 avril 2009). Paris, Édit. du CTHS, p. 141-152. (Documents préhistoriques, 29) ISBN 978-2-7355-0766-5.

PELEGRIN J. et SORESSI M. 2007 - Le Châtelperronien et ses rapports avec le Moustérien. In : B. Vandermeersch et B. Maureille (dirs). Les Néandertaliens. Biologie et cultures. Paris : Editions du CTHS, p. 283-296 (coll. Documents préhistoriques, 23).

PESESSE D., MICHEL A. 2006 - Le burin des Vachons : apports d'une relecture technologique à la compréhension de l'Aurignacien récent du nord de l'Aquitaine et des Charentes. PalEo, 18, p. 143-160.

RICHARD M., FALGUÈRES C., GHALEB B., RICHTER D. 2016 a - Résultats préliminaires des datations par ESR/U-Th sur émail dentaire, Grotte de La Verpillière I \& II, In: Project Collectif de Recherche: Le Paléolithique supérieur ancien en Bourgogne méridionale. Genèse, chronologie et structuration interne, évolution culturelle et technique. Rapport annuelle 2015. Abteilung für Ältere Urgeschichte und Quartärökologie, Sérvice Régional d'Archéologie Bourgogne, Tübingen, Dijon, p. 11-23.

RICHARD M., FALGUÈRES C., GHALEB D., ZÖLLER L., FRICK J.A., HOYER C., FLOSS H. 2016 b Enjeux et méthodologie des datations par ESR/U-Th de sites de la fin du Paléolithique Moyen. Présentation des données préliminaires des Grottes de La Verpillière I et II. Poster Q10 AFEQ CNFINQUA, Paléoclimats et environnements quaternaires, quoi de neuf sous le soleil ? Bordeaux (16-18 février 2016).

RIOS-GARAIZAR J. 2008 - Nivel IX (Châtelperroniense) de Labeko Koba (Arrasate-Gipuzkoa): gestión de la industria lítica y función del sitio, Munibe, 59, p. 25-46.

RIOS-GARAIZAR J., LIBANO SILVENTE I., GARATE MAIDAGAN D. 2012 - El yacimiento Châtelperroniense al aire libre de Aranbaltza (Barrika, Euskadi). Munibe, 63, p. 81-92.

ROUSSEL M. 2011 - Normes et variations de la production lithique Durant le Châtelperronien: la séquence de la Grande-Roche-de-la-Plématrie à Quinçay (Vienne). Thèse de doctorat en Préhistoire de l'Université Paris Ouest-Nanterre, 2011. 540p. 
ROUSSEL M. 2013 - Méthodes et rythmes du débitage laminaire au Châtelperronien: comparaison avec le Proto-Aurignacien. Comptes Rendus Palevol, 12, p. 233-241.

ROUSSEL M. 2014 - Des Lamelles retouchées au Châtelperronien : Diffusion d'Idées entre derniers Néandertaliens et premiers Hommes modernes migrants. In : M. Otte, F. Le Brun-Ricalens (Eds.), Modes de contacts et de déplacements au paléolithique eurasiatique. Actes du Colloque international de la commission 8 (Paléolithique supérieur) de l'UISPP (28-31 mai 2012), Liège, Université de Liège, p. 491-510.

ROUSSEL M., SORESSI M. 2010 - La Grande Roche de la Plématrie à Quinçay (Vienne). L'évolution du Châtelperronien revisitée. In : J. Buisson-Catil, J. Primault (Eds.), Préhistoire entre Vienne et Charente. Hommes et sociétés du Paléolithiques. Chauvigny, Association des Publications Chauvinoises, p. 203-219.

ROUSSEL M., SORESSI M. 2014 - Le Châtelperronien. In: Otte, M.(Ed.), Néandertal - Cro Magnon. La Rencontre. Arles, Editions Errance, p. 31-59.

ROUSSEL M., SORESSI M., HUBLIN J.-J. 2016 - The Châtelperronian conundrum: Blade and bladelet lithic technologies from Quinçay, France. Journal of Human Evolution, 95, p. 13-32.

RUEBENS K., MCPHERRON S.J.P., HUBLIN J.-J. 2015 - On the local Mousterian origin of the Châtelperronian: Integrating typo-technological, chronostratigraphic and contextual data. Journal of Human Evolution, 86, p. 55-91.

SZMIDT C., BROU L., JACCOTTEY L. 2010 - Direct radiocarbon (AMS) dating of split-based points from the (Proto)Aurignacian of Trou de la Mère Clochette, Northeastern France. Implications for the characterization of the Aurignacian and the timing of technical innovations in Europe. Journal of Archaeological Science 37 (12): 3320-3337.

SORESSI M. 2002 - Le Moustérien de tradition acheuléenne du sud-ouest de la France. Discussion sur la signification du faciès à partir de l'étude comparée de quatre sites : Pech-de-l'Azé I, Le Moustier, La Rochette et la Grotte XVI. . Thèse de doctorat en Géologie-Préhistoire de l'Université de Bordeaux I, 2002. $330 \mathrm{p}$.

SORESSI M., ROUSSEL M. 2014 - European Middle to Upper Paleolithic Transitional Industries : Châtelperronian. In: C. Smith (Ed.), Encyclopedia of Global Archaeology. New York, Springer, p. 2679-2693.

SONNEVILLE-BORDES D. (de), PERROT J. 1956 - Lexique typologique du Paléolithique supérieur. Bulletin de la Société préhistorique française, 53, 9, p. 547-559.

TARTAR E., HECKEL C. 2016 - Les productions en matières osseuses de la grotte de La Verpillière I. In: Fouilles programmés pluriannuelles aux sites paléolithiques des Grottes de La Verpillière I \& II à Germolles, commune de Mellecey (Saône-et-Loire). Rapport annuel 2015, rapport pluriannuel 2013 à 2015. Abteilung für Ältere Urgeschichte und Quartärökologie, Service Régional d'Archéologie Bourgogne, Tübingen, Dijon, p. 191-217.

VILLA P., BOSCATO P., RANALDO F., RONCHITELLI A. 2009 - Stone tools for the hunt: points with impact scars from a Middle Paleolithic site in southern Italy. Journal of Archaeological Science, 36, p. 850-859.

WEGENG H. 2015 - Das Protoaurignacien von Germolles (Saône-et-Loire, Frankreich). Tübingen : Eberhard Karls Universität Tübingen, 2015. Thèse de bachelor, 100p.

WEGENG H., FLOSS H. 2016 - The Proto-Aurignacian in the Grotte de La Verpillière I (Germolles, Saône-et-Loire). In : Rapport annuel 2015, rapport pluriannuel 2013 à 2015. Abteilung für Ältere 
Urgeschichte und Quartärökologie, Service Régional d'Archéologie Bourgogne, Tübingen, Dijon, p. 175-187.

WÜRSCHEM H. 2015 - Das Châtelperronien der Grotte de La Verpillière I (Saône-et-Loire, Frankreich). Tübingen : Eberhard Karls Universität Tübingen, 2015. Thèse de bachelor, 133 p.

ZÖLLER L., SCHMIDT C. 2016 - Germolles - Grotte de La Verpillière II - GH 3 \& 4, Report on luminescence dating of cave sediments. In: Project Collectif de Recherche: Le Paléolithique supérieur ancien en Bourgogne méridionale. Genèse, chronologie et structuration interne, évolution culturelle et technique. Rapport annuel 2015. Abteilung für Ältere Urgeschichte und Quartärökologie, Service Régional d'Archéologie Bourgogne, Tübingen, Dijon, p. 45-49.

\section{ABSTRACTS}

The Grotte de la Verpillière I in Germolles (Saône-et-Loire, France) has yielded an archaeological sequence from the Middle Palaeolithic to the Gravettian period. This contribution focusses on the Châtelperronian lithic industry, covering 150 years of research. From a techno-typological point of view, all known lithic objects presumably dating to this period are subject of this investigation. This study includes in-situ observations of Châtelperronian layers, as part of our own recent excavations. The lithic assemblage is put into context with other Châtelperronian samples in Southern Burgundy and Eastern France.

INDEX

Keywords: Châtelperronian, Germolles, Grotte de La Verpillière I, techno-typological analysis, Southern Burgundy, Eastern France

\section{AUTHORS}

\section{HARALD FLOSS}

Eberhard Karls Universität Tübingen, Institut für Ur- und Frühgeschichte und Archäologie des Mittelalters, Abteilung Ältere Urgeschichte und Quartärökologie, Schloss, Burgsteige 11, DE-72070 Tübingen - harald.floss@uni-tuebingen.deUMR6298 ARTeHIS, PCR « Le Paléolithique supérieur en Bourgogne méridionale », Université de Bourgogne, 6 Boulevard Gabriel, FR-21000 Dijon

\section{CHRISTIAN HOYER}

Eberhard Karls Universität Tübingen, Institut für Ur- und Frühgeschichte und Archäologie des Mittelalters, Abteilung Ältere Urgeschichte und Quartärökologie, Schloss, Burgsteige 11, DE-72070 Tübingen - christian.hoyer@uni-tuebingen.deUMR6298 ARTeHIS, PCR «Le Paléolithique supérieur en Bourgogne méridionale », Université de Bourgogne, 6 Boulevard Gabriel, FR-21000 Dijon

\section{HEIKE WÜRSCHEM}

Eberhard Karls Universität Tübingen, Institut für Ur- und Frühgeschichte und Archäologie des Mittelalters, Abteilung Ältere Urgeschichte und Quartärökologie, Schloss, Burgsteige 11, DE-72070 Tübingen - heike.wuerschem@student.uni-tuebingen.de 